Article

\title{
Low-Level Endothelial TRAIL-Receptor Expression Obstructs the CNS-Delivery of Angiopep-2 Functionalised TRAIL-Receptor Agonists for the Treatment of Glioblastoma
}

\author{
Nivetha Krishna Moorthy ${ }^{1}$, Oliver Seifert ${ }^{1,2}{ }^{1}$, Stephan Eisler ${ }^{1,2}$, Sara Weirich ${ }^{3}$, Roland E. Kontermann ${ }^{1,2}$, \\ Markus Rehm ${ }^{1,2}$ and Gavin Fullstone ${ }^{1,2, *(1)}$
}

1 Institute of Cell Biology and Immunology, University of Stuttgart, Allmandring 31, 70569 Stuttgart, Germany; nivetha.k@izi.uni-stuttgart.de (N.K.M.); oliver.seifert@izi.uni-stuttgart.de (O.S.); stephan.eisler@srcsb.uni-stuttgart.de (S.E.); roland.kontermann@izi.uni-stuttgart.de (R.E.K.); markus.morrison@izi.uni-stuttgart.de (M.R.)

2 Stuttgart Research Center Systems Biology, University of Stuttgart, Nobelstrasse 15, 70569 Stuttgart, Germany

3 Institute of Biochemistry and Technical Biochemistry, University of Stuttgart, Allmandring 31, 70569 Stuttgart, Germany; sara.weirich@ibtb.uni-stuttgart.de

* Correspondence: gavin.fullstone@izi.uni-stuttgart.de; Tel.: +49-711-68569303

check for updates

Citation: Krishna Moorthy, N.; Seifert, O.; Eisler, S.; Weirich, S.; Kontermann, R.E.; Rehm, M.; Fullstone, G. Low-Level Endothelial TRAIL-Receptor Expression Obstructs the CNS-Delivery of Angiopep-2 Functionalised TRAIL-Receptor Agonists for the Treatment of Glioblastoma. Molecules 2021, 26, 7582. https://doi.org/ $10.3390 /$ molecules 26247582

Academic Editors: Drazen Raucher and Jean-Marc Sabatier

Received: 6 October 2021

Accepted: 10 December 2021

Published: 14 December 2021

Publisher's Note: MDPI stays neutral with regard to jurisdictional claims in published maps and institutional affiliations.

Copyright: (c) 2021 by the authors. Licensee MDPI, Basel, Switzerland. This article is an open access article distributed under the terms and conditions of the Creative Commons Attribution (CC BY) license (https:/ / creativecommons.org/licenses/by/ $4.0 /)$.

\begin{abstract}
Glioblastoma (GBM) is the most malignant and aggressive form of glioma and is associated with a poor survival rate. Latest generation Tumour Necrosis Factor Related Apoptosis-Inducing Ligand (TRAIL)-based therapeutics potently induce apoptosis in cancer cells, including GBM cells, by binding to death receptors. However, the blood-brain barrier (BBB) is a major obstacle for these biologics to enter the central nervous system (CNS). We therefore investigated if antibody-based fusion proteins that combine hexavalent TRAIL and angiopep-2 (ANG2) moieties can be developed, with ANG2 promoting receptor-mediated transcytosis (RMT) across the BBB. We demonstrate that these fusion proteins retain the potent apoptosis induction of hexavalent TRAIL-receptor agonists. Importantly, blood-brain barrier cells instead remained highly resistant to this fusion protein. Binding studies indicated that ANG2 is active in these constructs but that TRAIL-ANG2 fusion proteins bind preferentially to BBB endothelial cells via the TRAIL moiety. Consequently, transport studies indicated that TRAIL-ANG2 fusion proteins can, in principle, be shuttled across BBB endothelial cells, but that low TRAIL receptor expression on BBB endothelial cells interferes with efficient transport. Our work therefore demonstrates that TRAIL-ANG2 fusion proteins remain highly potent in inducing apoptosis, but that therapeutic avenues will require combinatorial strategies, such as TRAIL-R masking, to achieve effective CNS transport.
\end{abstract}

Keywords: glioblastoma; TRAIL; angiopep-2; CNS delivery; receptor-mediated transcytosis; blood-brain barrier

\section{Introduction}

Glioblastoma (GBM), a grade IV astrocytoma [1], is the most prevalent and deadly form of primary cancer of the central nervous system (CNS) with the rate of incidence of 3.22 cases per 100,000 people [2]. Despite standard of care treatment of surgery followed by concomitant radiotherapy and chemotherapy [3], outcomes for GBM patients are extremely poor with a median survival of $\sim 14$ months [4,5]. Therefore, new treatment options are urgently required to improve patient outcomes. Agonists of the tumour necrosis factor (TNF)-related apoptosis-inducing ligand (TRAIL) receptors, TRAIL-R1 and TRAIL-R2, are one such potential treatment option. TRAIL receptor agonists, upon TRAILR1/R2 receptor aggregation, induce the extrinsic pathway of apoptosis exclusively in cancer cells whilst leaving normal cells intact [6-8]. Recently, second-generation TRAIL-receptor agonists were developed that show improved in vivo half times and cancer cell cytotoxicity [9-11]. 
Fc-scTRAIL is a second-generation TRAIL-receptor agonist, produced by fusion of a singlechain TRAIL (scTRAIL) trimer to the Fc region of an IgG, resulting in an overall hexavalent TRAIL-receptor agonist that potently engages TRAIL receptor-mediated apoptosis in a wide range of cancer cells [12-16]. The penetration of large biologics, such as TRAIL, into the CNS, is generally prevented by the presence of the blood-brain barrier (BBB), with approximately $0.1 \%$ of injected antibody doses reaching the brain parenchyma [17-19]. Whilst the BBB blocks almost all passive entry of biologics into the CNS, it actively transports select proteins and lipoproteins across the BBB by the process of receptor-mediated transcytosis (RMT) [20,21]. RMT is initiated by binding specific receptors on the BBB, invoking endocytosis of the cargo into a transport vehicle, whereupon the vesicle is trafficked to the opposite side of the BBB and exocytosed into the CNS parenchyma $[17,18,22,23]$. Many RMT targets at the BBB have been established, including the transferrin receptor (TfR) $[21,24,25]$ low-density lipoprotein (LDL) receptor-related protein (LRP1) [26-28] and the insulin receptor [19,29]. Notably, despite the identification of RMT in the 1980s and the recent observation that entry of endogenous proteins into the CNS by RMT was much higher than originally thought [30], therapeutics based on the concept of RMT have yet to translate into clinically approved drugs.

Angiopep-2 (ANG2) is a small 19 amino acid peptide that was shown to induce LRP1dependent RMT across the BBB $[26,31]$ and it was used to increase CNS-penetrance of various cargo from small drugs to proteins to nanoparticle-based systems [32-34]. Recently, ANG2-based constructs have entered early phase I/II clinical trials, showing low toxicity (NCT01480583, NCT01967810, NCT02048059). In this work, we set out to explore whether ANG2-TRAIL fusion proteins can be generated without compromising the potency of the hexavalent TRAIL moiety to induce apoptotic cell death and if such a fusion protein can be transported across BBB endothelial cells through its ANG2 moiety.

\section{Results}

2.1. Design, Production and Purification of a CNS-Targeted Hexavalent TRAIL-Receptor Agonist

Second-generation hexavalent TRAIL fusion proteins have evolved as a potential treatment strategy against GBM $[13,35]$ but the poor ability of biologics to cross the BBB is severely limiting to their clinical implementation. To address the complex problem of transporting high molecular weight TRAIL variants across the BBB, we fused TRAIL receptor agonists to ANG2, a synthetic peptide known to undergo transcytosis via the LRP1 receptor [26,31]. We included three functional units, the crystallisable fragment $(\mathrm{Fc})$ domain of a human IgG including the hinge region, a single-chain format of trimeric TRAIL (scTRAIL) and ANG2. These units confer the final construct with dimerisation (Fc; Figure 1(Ai)), apoptosis induction (scTRAIL; Figure 1(Aii)) and CNS targeting (ANG2; Figure 1(Aiii)) properties. To induce effective apoptosis, we previously generated FcscTRAIL, consisting of two trivalent scTRAIL units dimerised via their fusion to the C-terminus of an Fc from human IgG1, creating the overall hexavalent TRAIL receptor agonists demonstrated to have improved cytotoxicity $[12,13]$ (Figure $1(\mathrm{Bi}, \mathrm{Ci})$ ). We now also created a CNS-targeted hexavalent TRAIL-receptor agonist by fusing scTRAIL to the Nterminus of human IgG1 Fc and ANG2 to the C-terminus of Fc interspaced with a flexible glycine-serine linker $\left(\mathrm{G}_{4} \mathrm{~S}\right)_{2}$ (Figure 1 (Bii)). The resulting hexavalent TRAIL construct included two ANG2 moieties per molecule (Figure 1(Cii)). As an additional control, we generated scTRAIL-ANG2, a single ANG2 fused to the C-terminus of scTRAIL interspaced with a glycine-serine linker $\left(\mathrm{G}_{2} \mathrm{SG}_{2}\right)_{2}$ (Figure 1(Biii,Ciii)). Notably, we created our TRAILANG2 fusion proteins (Figure 1(Biii,Ciii)) with ANG2 on the C-terminus in accordance with previous studies [36,37]. To determine if C-terminal fusion was only a convention or serves functional purposes, we created two separate ANG2-positive control proteins by fusing ANG2 to the $\mathrm{C}$ - or $\mathrm{N}$-terminal end of an $\mathrm{Fc} \gamma$ receptor binding ( $\mathrm{Fc} \gamma \mathrm{R})$-deficient mutant Fc $\left(\mathrm{Fc}^{\Delta \mathrm{ab}}\right)[38]$, interspaced with a glycine-serine linker $\left(\mathrm{G}_{4} \mathrm{~S}\right)_{2}$ (Figure 1(Biv,v,Civ,v)). 
(A) i. Fc: Dimerisation

Hinge-Fc



ii. scTRAIL: Cancer Cell Apoptosis Induction

\begin{tabular}{|l|l|l|l|l|}
\hline TRAIL & G & TRAIL & G & TRAIL \\
\hline
\end{tabular}

iii. Angiopep-2:

CNS-targeting

Angiopep-2

(B) i. FC-scTRAIL

\begin{tabular}{|l|l|l|l|l|l|l|}
\hline $\mathbf{L}$ & $\mathbf{F}$ & Hinge-Fc \\
\hline
\end{tabular}

ii. scTRAIL-Fc-ANG2

\begin{tabular}{|l|l|l|l|l|l|l|}
\hline L & F & TRAIL & G & TRAIL & G & TRAIL \\
\hline
\end{tabular}

iii. ScTRAIL-ANG2

\begin{tabular}{|l|l|l|l|l|l|l|}
\hline L & F & TRAIL & G & TRAIL & G & TRAIL \\
\hline
\end{tabular}

iv. $\triangle \mathrm{Fc}-\mathrm{ANG} 2$

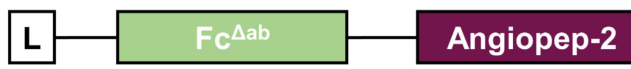

v. ANG2- $\triangle \mathrm{Fc}$

$\mathrm{L}$ Angiopep-2 $\mathrm{Fc}^{\mathrm{Aab}}$

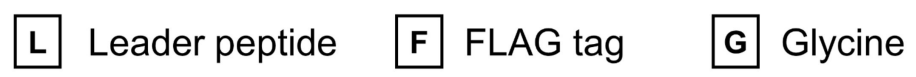

(C)

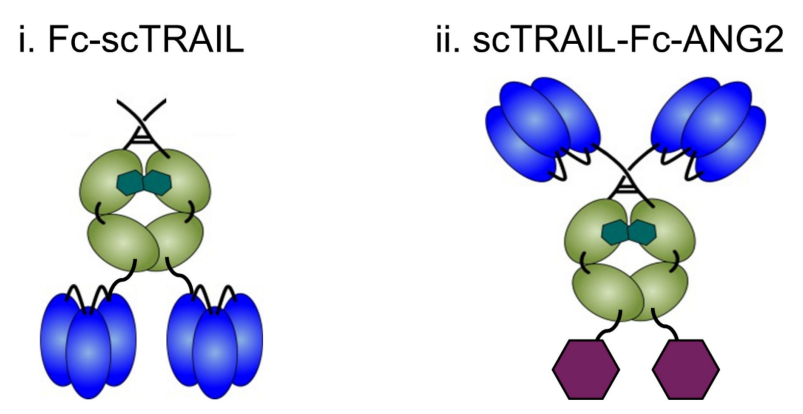

iii. ScTRAIL-ANG2

iv. $\mathrm{Fc}^{\triangle \mathrm{ab}-\mathrm{ANG} 2}$

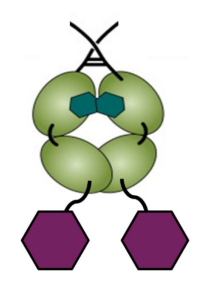

v. ANG2-Fc ${ }^{\triangle a b}$

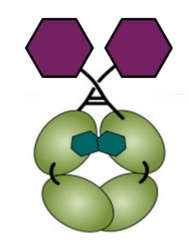

Figure 1. Designing a CNS-targeted TRAIL-receptor agonist. (A) Functional units, (B) composition and (C) schematic assembly of CNS-targeted scTRAIL variants and relevant control proteins. 
The proteins were produced in HEK293-6E cells, purified and analysed for purity, stability, aggregation and correct oligomerisation. In size-exclusion chromatography (SEC), we obtained a single peak of each protein with no unexpected aggregation, demonstrating a high purity and stability of the construct (Figure S1A). In SDS-PAGE, we observed clear bands with no degradation and the proteins ran at their predicted molecular mass, in both reducing (monomeric) and non-reducing (dimeric) conditions (Figure S1B). The presence of ANG2 in scTRAIL-Fc-ANG2 was also confirmed by MALDI-TOF mass spectrometry (Figure S2). Therefore, we designed and successfully purified fusion proteins and relevant control proteins to combine the potent and specific anti-cancer properties of hexavalent TRAIL-receptor agonists with enhanced CNS delivery properties of ANG2.

\subsection{Fusion of ANG2 to Hexavalent TRAIL Maintains Its Potency in Inducing Apoptosis}

First, we sought to confirm that the addition of ANG2 does not affect TRAILmediated activation of caspases. Thereby, we analysed caspase cascade signalling in the GBM cell line A172 and a well-characterised TRAIL-responsive human colon cancer cell line HCT116 in response to equimolar amounts of the TRAIL trimer, i.e., $1 \mathrm{nM}$ hexavalent scTRAIL-Fc-ANG2 or $2 \mathrm{nM}$ trivalent scTRAIL-ANG2. The hexavalent construct scTRAIL-Fc-ANG2 induced robust processing of the initiator procaspase-8, the downstream effector procaspase-3, and the caspase-3 substrate PARP. Processing of the caspases was inhibited by the pan-caspase inhibitor Q-VD-Oph in A172 and HCT116 cells (Figure 2A). The trivalent TRAIL construct, scTRAIL-ANG2, induced only minor processing of apoptosis signalling mediators in both cell lines. Having confirmed that ANG2-functionalised TRAIL-receptor agonists induce molecular hallmarks of apoptosis, we next determined cell death induction in A172 cells in response to Fc-scTRAIL, scTRAIL-Fc-ANG2 or scTRAIL-ANG2 by annexin V-PI staining and flow cytometry. We observed a strong response of cells to both hexavalent TRAIL constructs scTRAIL-FcANG2 and Fc-scTRAIL in a dose-dependent manner (Figure 2B). Moreover, the $\mathrm{EC}_{50}$ values of Fc-scTRAIL $(0.15 \mathrm{nM})$ and scTRAIL-Fc-ANG2 $(0.11 \mathrm{nM})$ stayed in a similar range, demonstrating that the addition of ANG2 did not affect the TRAIL potency in killing cells. We also showed similar results in HCT116 cells using a crystal violet assay with $\mathrm{EC}_{50}$ values of $0.13 \mathrm{nM}$ (Fc-scTRAIL) and $0.025 \mathrm{nM}$ (scTRAIL-Fc-ANG2) (Figure 2C). In contrast, we observed poor responsiveness of A172 cells to the trivalent scTRAILANG2 construct, with only a 30\% loss of cell viability at the highest concentration of $4 \mathrm{nM}$ (Figure 2B). This demonstrates that the enhanced clustering from hexavalent TRAILreceptor agonists is essential for efficient apoptosis induction. Furthermore, hexavalent TRAIL constructs maintain their potency in inducing apoptosis after the addition of the ANG2 moiety. 
(A)

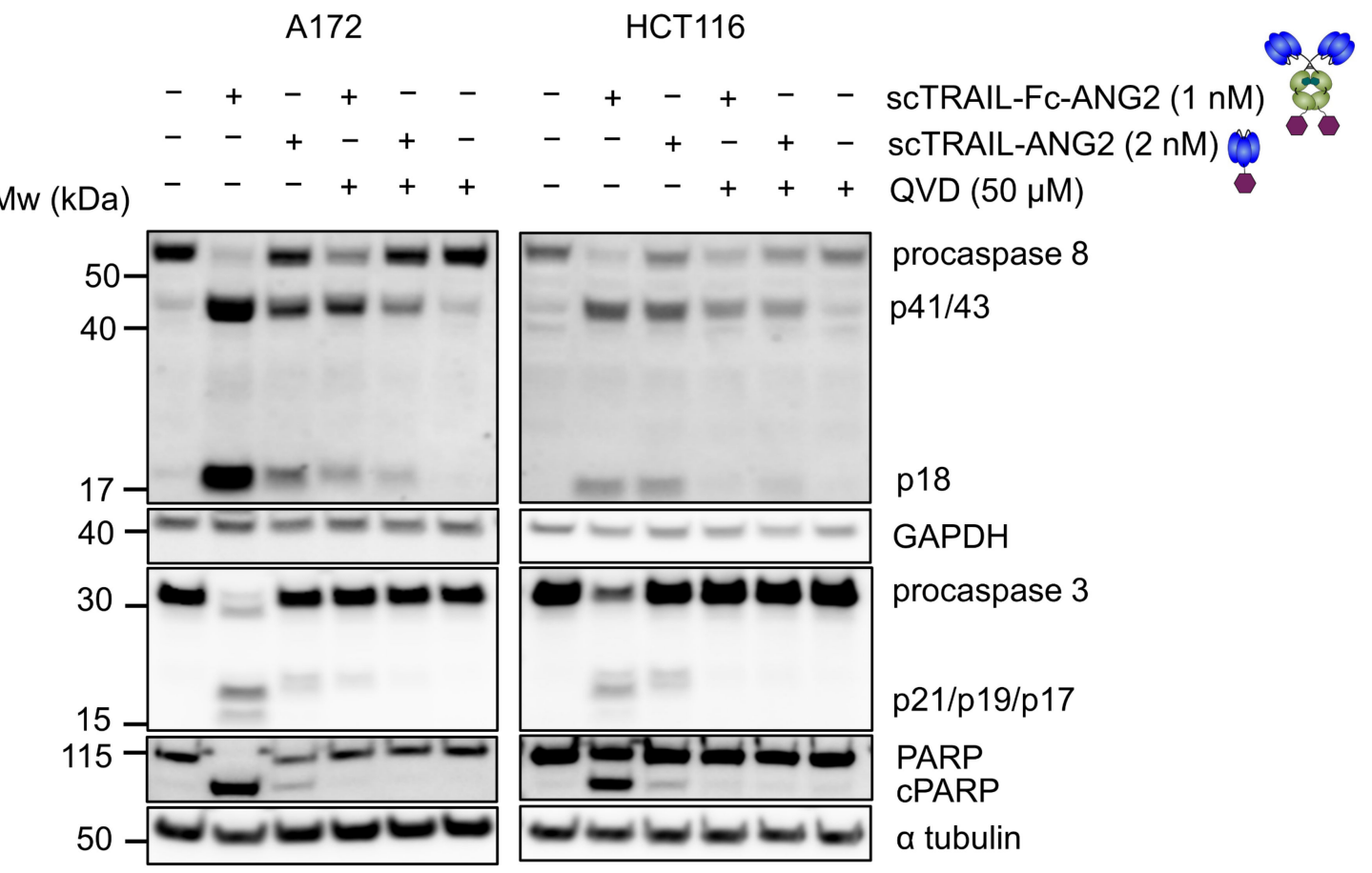

(B)
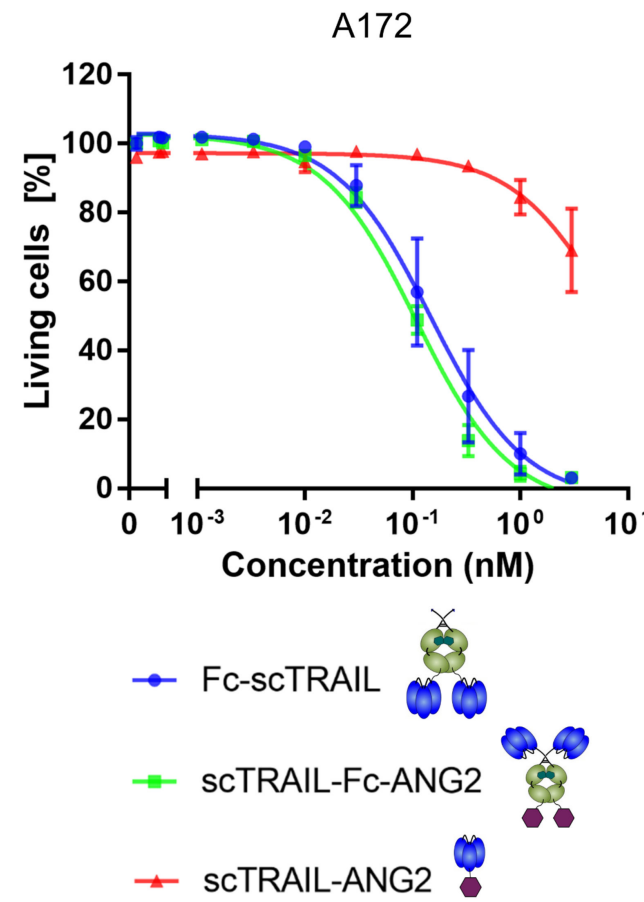

(C)
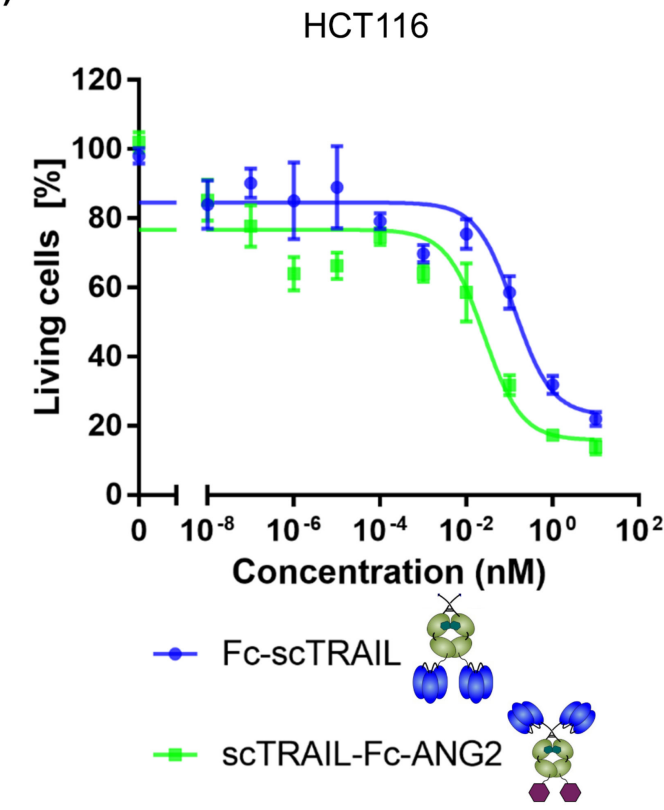

Figure 2. ANG2 fusion does not affect the hexavalent TRAIL potency against cancer cells. (A) A172 and HCT116 cells were treated with $1 \mathrm{nM}$ of scTRAIL-Fc-ANG2 or $2 \mathrm{nM}$ of scTRAIL-ANG2 for $6 \mathrm{~h}$ with or without $50 \mu \mathrm{M}$ QVD and blotted for procaspase 8 , cleaved caspase 8 (p18), procaspase 3, cleaved caspase 3 (p21/p19/p17), PARP and cleaved PARP (cPARP). GAPDH and $\alpha$ tubulin served as loading controls. Representative western blots from two independent experiments are shown. (B) A172 glioblastoma cells were treated with varying concentrations of indicated construct for $24 \mathrm{~h}$ and viable cells were determined by Annexin V-PI negativity using flow cytometry. Data are shown as mean \pm SEM from three independent experiments. (C) Dose-dependent response of HCT116 colon cancer cells to Fc-scTRAIL or scTRAIL-Fc-ANG2 after $16 \mathrm{~h}$ stimulation with different concentrations of the constructs. Cell viability was measured by crystal violet assay. Data show results from one representative experiment. 


\subsection{Blood-Brain Barrier Cells Are Highly Resistant to TRAIL Treatment}

TRAIL induces apoptosis by engaging with TRAIL receptors on the cell surface, therefore we quantified the number of surface TRAIL receptors on the human BBB endothelial cell line hCMEC/D3 and compared them to TRAIL-responsive HCT116 cells using flow cytometry. The hCMEC/D3 cells showed significantly lower expression of death receptors, TRAIL-R1 and TRAIL-R2, compared to HCT116 cells (Figure 3A). Importantly, these two receptors are the key mediators of downstream apoptosis signalling in response to TRAIL [39-41]. The decoy receptors, TRAIL-R3 and TRAIL-R4, were expressed at low levels in both cell lines with a marginal decrease in TRAIL-R4 in hCMEC/D3 cells compared to HCT116 cells (Figure 3A). This suggests that hCMEC/D3 cells and BBB endothelial cells may be more TRAIL-resistant than cancer cells. We therefore analysed apoptotic caspase signalling in hCMEC/D3 and the murine BBB endothelial cell line bEnd.3 for responses to hexavalent TRAIL by treatment with a low $(0.1 \mathrm{nM})$ and a high $(4 \mathrm{nM})$ concentration of Fc-scTRAIL for $6 \mathrm{~h}$. As expected, even at the higher concentration of Fc-scTRAIL only residual accumulation of cleaved subunits was observed in hCMEC/D3 cells (Figure 3B), whereas no caspase processing was observed in bEnd.3 cells (Figure 3C). To confirm resistance of blood-brain barrier cells to TRAIL treatment, we determined the percentage of living hCMEC/D3 cells in response to Fc-scTRAIL, scTRAIL-Fc-ANG2 or scTRAILANG2 by annexin V-PI staining and flow cytometry. We observed only residual loss in viability even at very high concentrations of $3 \mathrm{nM}$ (Figure 3D). At the same concentration, nearly 100\% cell death in A172 cells was achieved (Figure 2A). Furthermore, at the EC50 concentration for A172 cells ( $0.11 \mathrm{nM})$, hCMEC/D3 cells showed absolutely no discernible cell death (Figure 3D). The additional BBB endothelial cell line, bEnd.3, was also resistant to TRAIL-mediated viability loss (Figure 3E). Altogether, these data demonstrate that blood-brain barrier cells are resistant to TRAIL treatment, which corresponds to their low expression of the death receptors TRAIL-R1 and TRAIL-R2. 
(A)
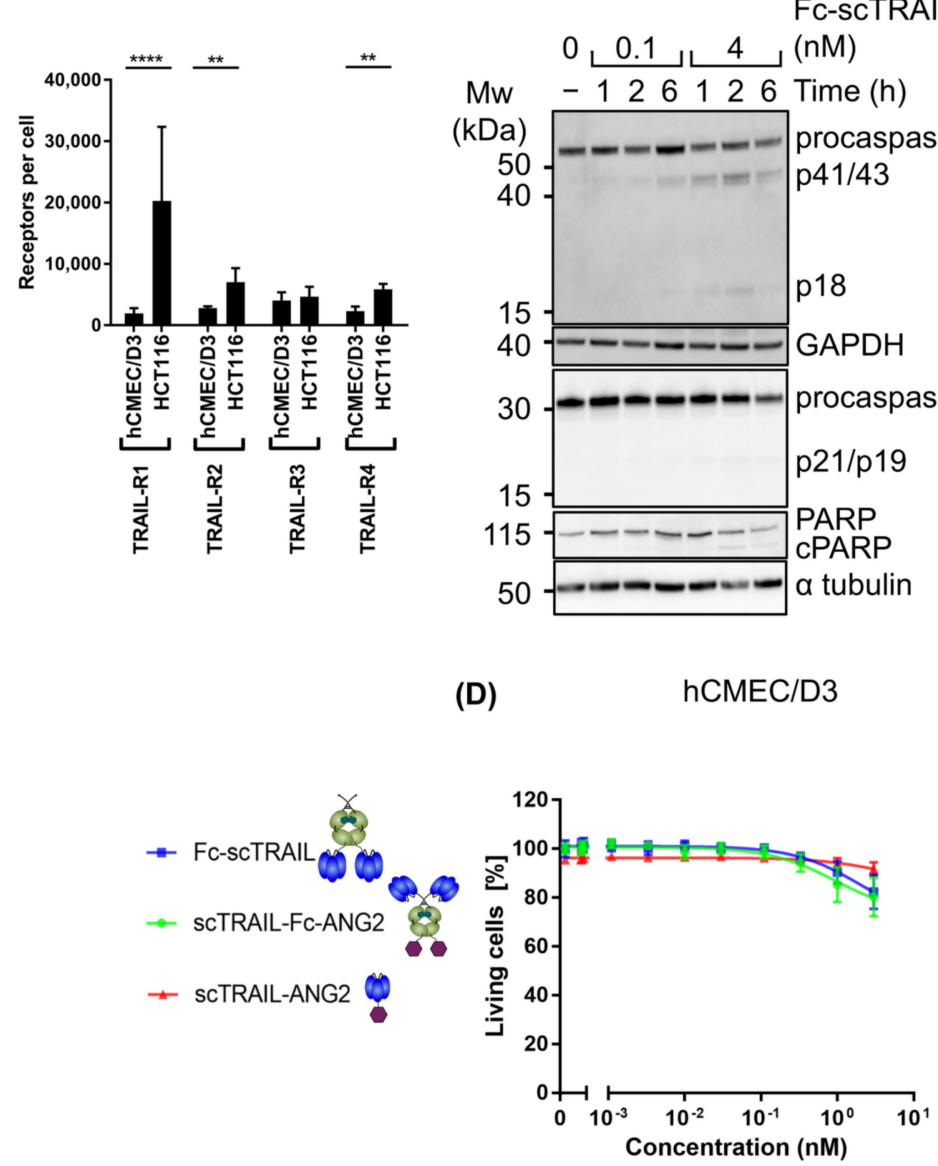

(D)

(B)

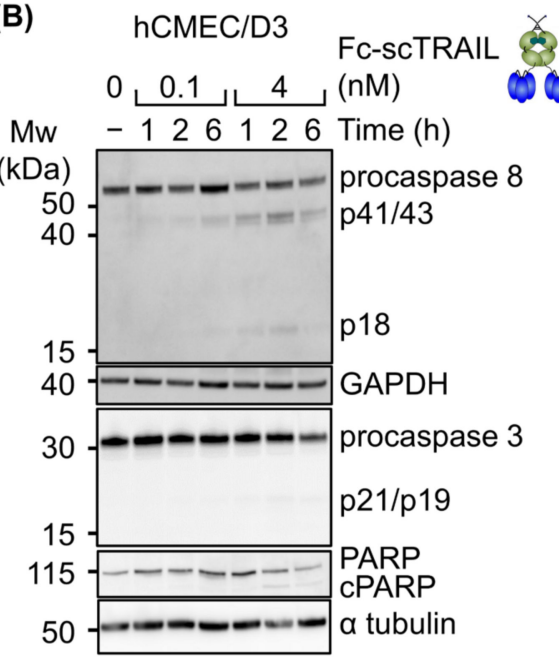

hCMEC/D3

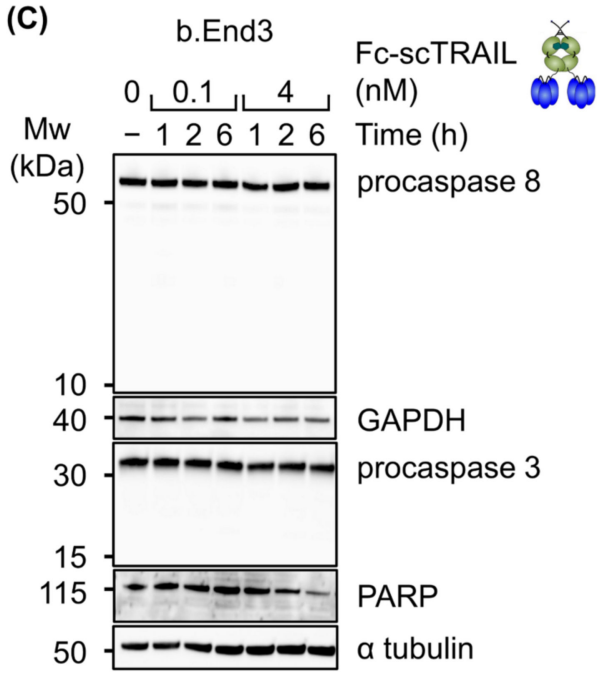

(E)

bEnd.3

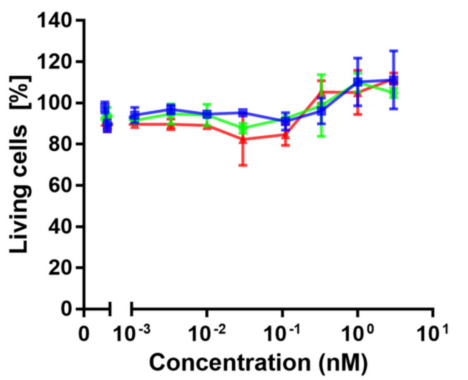

Figure 3. Blood-brain barrier cells are highly resistant to TRAIL treatment. (A) Surface expression of TRAIL-R1, TRAIL-R2, TRAIL-R3, TRAIL-R4 receptors in hCMEC/D3 and HCT116 cells were quantified by the QIFIKIT and flow cytometry. The mean $\pm \mathrm{SD}$ of three independent experiments is shown. Statistical significance was tested by Tukey's two-way ANOVA on log-transformed receptor values: ${ }^{* * * *}=p<0.0001,{ }^{* *}=p<0.01$. (B) hCMEC/D3 cells were treated with the indicated concentration of Fc-scTRAIL for 1, 2 or $6 \mathrm{~h}$ and then analysed for procaspase 8 , cleaved caspase 8 (p18/p10), procaspase 3 and cleaved caspase 3 (p21/p19/p17) by western blotting. Representative images from two independent experiments are shown. (C) bEnd.3 cells were treated with the indicated concentration of Fc-scTRAIL for 1, 2 or $6 \mathrm{~h}$ and then analysed for procaspase 8 , cleaved caspase 8 (p18/p10), procaspase 3 and cleaved caspase 3 (p21/p19/p17) by western blotting. Representative images from two independent experiments are shown. (D) hCMEC/D3 cells were treated with indicated construct for $24 \mathrm{~h}$. Viable cells were determined by Annexin V-PI negativity using flow cytometry. Data are shown as mean \pm SEM from three independent experiments. (E) bEnd.3 cells were treated with indicated construct for $24 \mathrm{~h}$. Viable cells were determined by MTT assay. Data are shown as mean \pm range from two independent experiments.

\subsection{Binding of CNS-Targeted TRAIL Fusion Proteins to Blood-Brain Barrier Cells Is Predominantly TRAIL-Mediated}

Having confirmed that BBB endothelial cells are resistant to TRAIL-mediated apoptosis, we next set out to characterise the modality of binding of TRAIL-ANG2 fusion proteins with blood-brain barrier cells. First, we sought to confirm the expression of the ANG2-target receptor LRP1 on human and mouse BBB endothelial cells. Surprisingly, western blot analysis and flow cytometry measurements demonstrated that hCMEC/D3 cells express very low levels of LRP1 compared to the known LRP1-expressing mouse embryonic fibroblasts (MEFs) [42] or bEnd.3 cells (Figures S3A and S3B). Therefore, we conducted subsequent binding and transport studies in bEnd.3 cells. Given that BBB endothelial cells express TRAIL-receptors, albeit, at low levels, we initially set out to determine whether TRAIL-ANG2 fusion proteins preferentially bind to blood brain barrier cells via their TRAIL- or ANG2-targeting moieties. Hereby, we first incubated bEnd.3 cells 
with Fc-scTRAIL or scTRAIL-Fc-ANG2 for $2 \mathrm{~h}$ at $4{ }^{\circ} \mathrm{C}$ to prevent internalisation and then measured the binding using flow cytometry. To determine the nature of the binding, we also pre-incubated TRAIL constructs with a 100-fold molar excess of a soluble recombinant TRAIL receptor (TRAIL-R2-Fc), engineered by fusing the extracellular domain of TRAIL-R2 to an Fc, to block TRAIL-mediated binding to target cells. We observed dose-dependent binding of the fusion proteins to bEnd.3 cells, however, the binding was strongly inhibited when blocking TRAIL (Figure S3C). This suggested that TRAIL-mediated binding dominated under these assay conditions. Given the reported low affinity (313 nM) of ANG2 for LRP1 [43], we reasoned that ANG2-binding to the cells at $4{ }^{\circ} \mathrm{C}$ may be too low for specific robust detection of surface binding. Indeed, as expected, the binding of various ANG2-positive control proteins, FLAG-ANG2, FITC-ANG2 or FITC-scrambled ANG2 (FITC-scrANG2) to bEnd. 3 cells at $4{ }^{\circ} \mathrm{C}$ was not detectable (Figure S3D). Moreover, the binding of FITC-ANG2 was not increased compared to scrambled control, suggesting the signal was predominantly due to non-specific interaction with the FITC-label. Therefore, we switched to an immunostaining-based analysis where we simultaneously observed both cell surface binding and uptake of constructs at $37^{\circ} \mathrm{C}$. Hereby, we incubated the cells with $50 \mathrm{nM}$ of $\mathrm{Fc}^{\Delta \mathrm{ab}}$-ANG2, ANG2-Fc ${ }^{\Delta \mathrm{ab}}$, Fc-scTRAIL or scTRAIL-Fc-ANG2 for $15 \mathrm{~min}$ or $30 \mathrm{~min}$ and imaged cells using confocal microscopy. We observed specific signals from positive control proteins $\mathrm{Fc}^{\Delta \mathrm{ab}}$-ANG2 and ANG2-Fc ${ }^{\Delta \mathrm{ab}}$ to bEnd. 3 cells after $15 \mathrm{~min}$ or $30 \mathrm{~min}$ incubation, as quantified by either counting of puncta (Figure $4 \mathrm{~A}, \mathrm{~B}$ ) or total cell fluorescence intensity (Figure 4C,D). Notably, binding was independent of whether ANG2 was fused to the N- or C-terminus of the protein. Strikingly, we observed a marked fold increase of between 2.9 and 4.5 in the intensity of binding of TRAIL-based constructs, Fc-scTRAIL and scTRAIL-Fc-ANG2, as compared to the ANG2-only positive controls (Figure 4C,D), in line with the flow cytometry experiments (Figure S3C,D). Moreover, signals from the TRAIL-based constructs were highly diffuse across the entire cell, whilst ANG2-only constructs were predominantly localised to the perinuclear region (Figure 4A,D), in line with the spatial expression pattern of its target receptor, LRP1 [44] (Figure S3E). TRAIL-R2$\mathrm{mFc}{ }^{\mathrm{LALA}}$, a fusion of the extracellular domain of the human TRAIL-R2 and the Fc-receptor binding mutant murine $\mathrm{Fc}\left(\mathrm{mFc}^{\mathrm{LALA}}\right)$, was used to prevent the non-specific signal from anti-human Fc-based detection and engagement of Fc-receptors. Blocking of TRAIL with a 100-fold molar excess of TRAIL-R2-mFc ${ }^{\text {LALA }}$, brought the binding back to the level of ANG2-only control proteins and returned the spatial distribution to the perinuclear region (Figure 4C,D). Taken together, these data demonstrate that ANG2 is functional within fusion proteins, but that despite low expression of TRAIL receptors on blood-brain barrier cell lines, masking or absence of TRAIL or TRAIL receptors is required for effective detection of ANG2-mediated binding. 
(A)
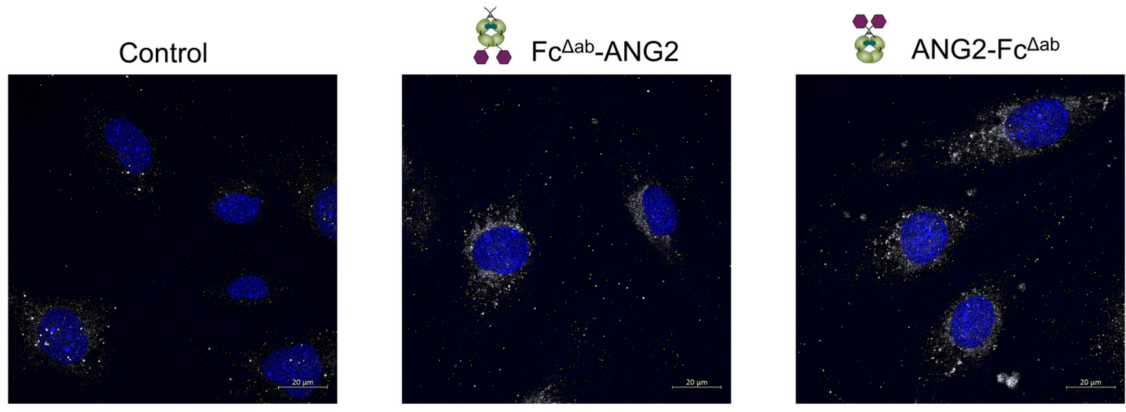

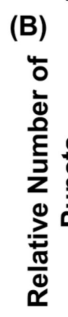

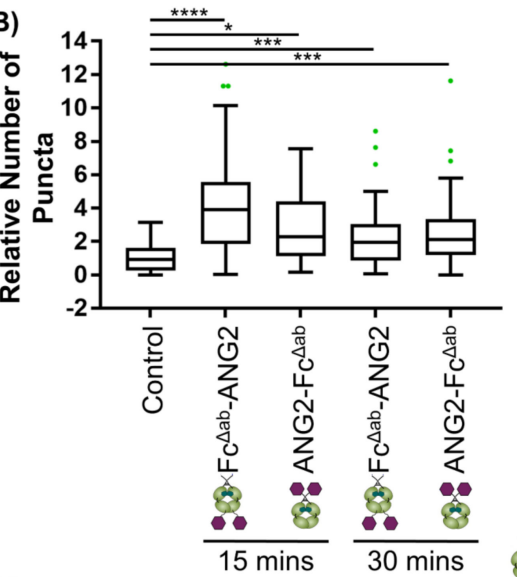

(C)

(D)
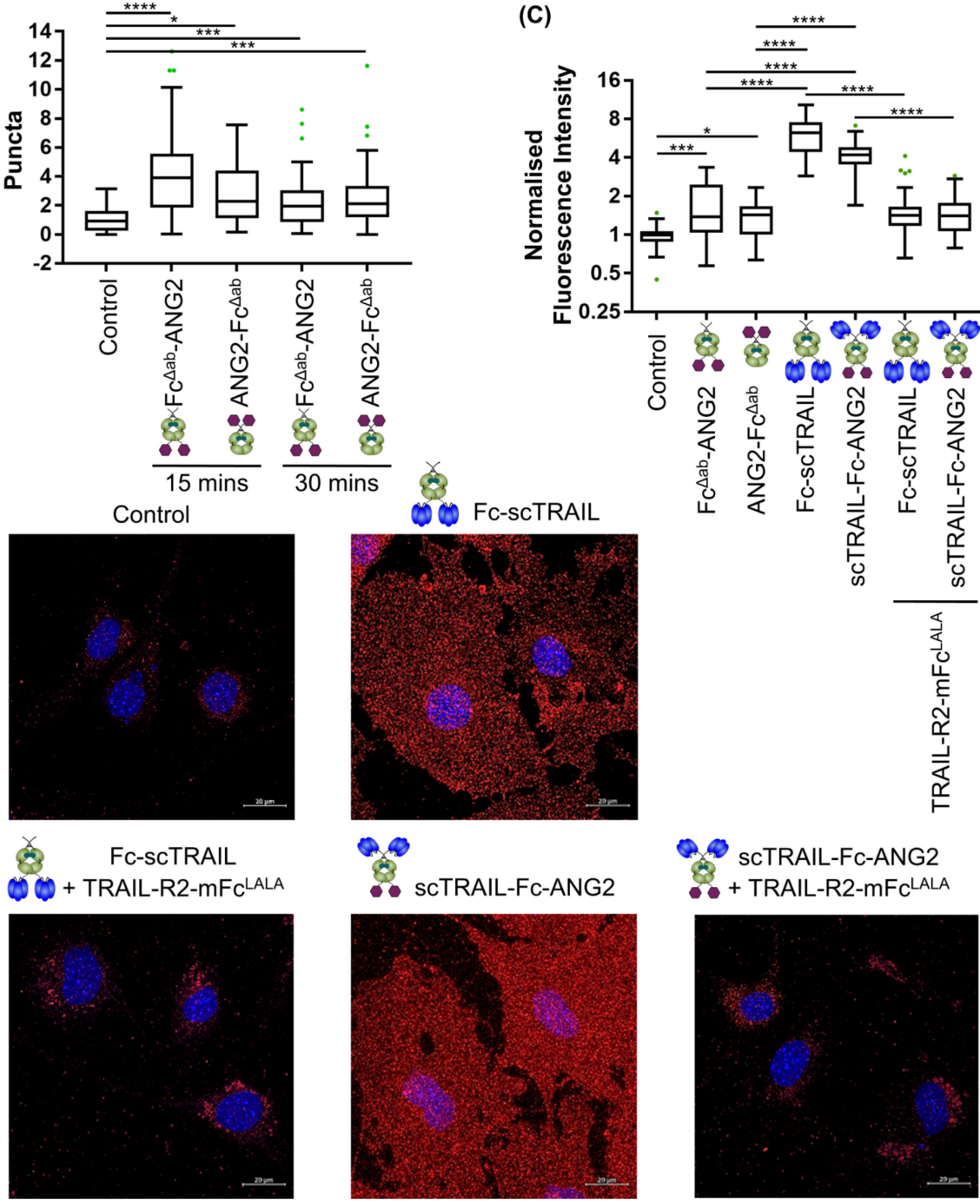

Figure 4. Binding to blood-brain barrier cells is predominantly TRAIL-mediated. (A) bEnd.3 cells were incubated with $50 \mathrm{nM}$ of indicated ANG2-control protein for $30 \mathrm{~min}$. Nuclei were stained in blue with Hoechst. White signal indicates the binding of the constructs. Scale bar $20 \mu \mathrm{m}$. (B) The number of vesicles from A were quantified at $15 \mathrm{~min}$ and $30 \mathrm{~min}$ and compared between control and ANG2-control protein conditions. Data were plotted as a Tukey boxplot with outliers represented as individual points, minimum of 44 cells per group pooled from three independent experiments. Statistical significance was tested by Tukey's two-way ANOVA: ${ }^{*}=p \leq 0.05 ;{ }^{* * *}=p \leq 0.001^{* * * *}=p \leq 0.0001$. (C) bEnd. 3 cells were incubated with $50 \mathrm{nM}$ of indicated construct for $15 \mathrm{~min}$ with or without $30 \mathrm{~min}$ pre-incubation of 100 -fold molar excess of TRAIL-R2-mFc ${ }^{\text {LALA }}$. The fluorescence intensity of the cells was quantified and compared between control and construct condition. Data were plotted as a Tukey boxplot with outliers represented as individual points, minimum 43 cells per group pooled from three independent experiments. Statistical significance was tested by non-parametric one-way ANOVA, Kruskal-Wallis test with Dunn's correction: ${ }^{*}=p \leq 0.05 ;{ }^{* * *}=p \leq 0.001{ }^{* * * *}=p \leq 0.0001$. (D) Representative images from C, nuclei were stained in blue with Hoechst. Red signal indicates binding of the constructs. Secondary antibody, anti-Fc-PE was used as a control for non-specific signal. Scale bar $20 \mu \mathrm{m}$. 


\subsection{CNS-Transport of TRAIL-Fusion Constructs}

Having established that scTRAIL-Fc-ANG2 binds both via ANG2 and TRAIL moieties to BBB endothelial cells, we next set out to characterise transcytosis of this fusion protein across BBB endothelial cells. We established an in vitro blood-brain barrier model by growing bEnd. 3 cells to a confluent layer on a transwell (Figure 5A) and obtained a steady barrier with a transendothelial electrical resistance (TEER) of $17 \Omega \cdot \mathrm{cm}^{2}$ (Figure S4). We then placed $20 \mathrm{nM}$ of $\mathrm{Fc}^{\Delta \mathrm{ab}}$-ANG2, ANG2-Fc ${ }^{\Delta \mathrm{ab}}, \mathrm{Fc}$-scTRAIL and scTRAIL-Fc-ANG2 in the apical compartment with or without $30 \mathrm{~min}$ pre-incubation with a 100-fold molar excess of soluble TRAIL-R2-mFc ${ }^{\text {LALA }}$. After $1 \mathrm{~h}$ incubation at $37^{\circ} \mathrm{C}$, we determined the concentration of fusion proteins in the apical and basolateral compartments using quantitative sandwich ELISA. ANG2-only positive control proteins, ANG2- $\mathrm{Fc}^{\mathrm{\Delta ab}}$ and $\mathrm{Fc}^{\Delta \mathrm{ab}}$-ANG2, were both detected after $1 \mathrm{~h}$ in the basolateral compartment (Figure $5 \mathrm{~B}$ ). In line with our finding that ANG2 binding was independent of whether ANG2 was fused to the $\mathrm{N}$ - or C-terminus of the protein, successful transport was also observed for both conformations of the ANG2-controls. On the contrary, scTRAIL-Fc-ANG2 was only detectable in the basolateral compartment after blocking of TRAIL through TRAIL-R2$\mathrm{mFc}^{\mathrm{LALA}}$. As expected, Fc-scTRAIL was not transported to the basolateral compartment, confirming that the ability to be transported is strictly ANG2-dependent. Overall, this indicates that binding to TRAIL receptors interferes with ANG2-mediated transport of scTRAIL-Fc-ANG2 across BBB endothelial cells, but that TRAIL-based biologics can be transported when interfering with TRAIL/TRAIL-R interactions on the apical side. This provides a rationale for TRAIL/TRAIL-R masking strategies outside of the CNS to allow for the transport of this potent apoptosis inducer into the brain.

(A)

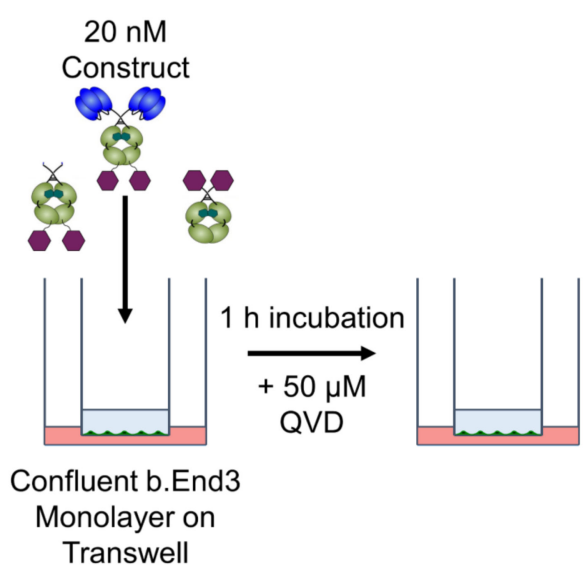

(B)

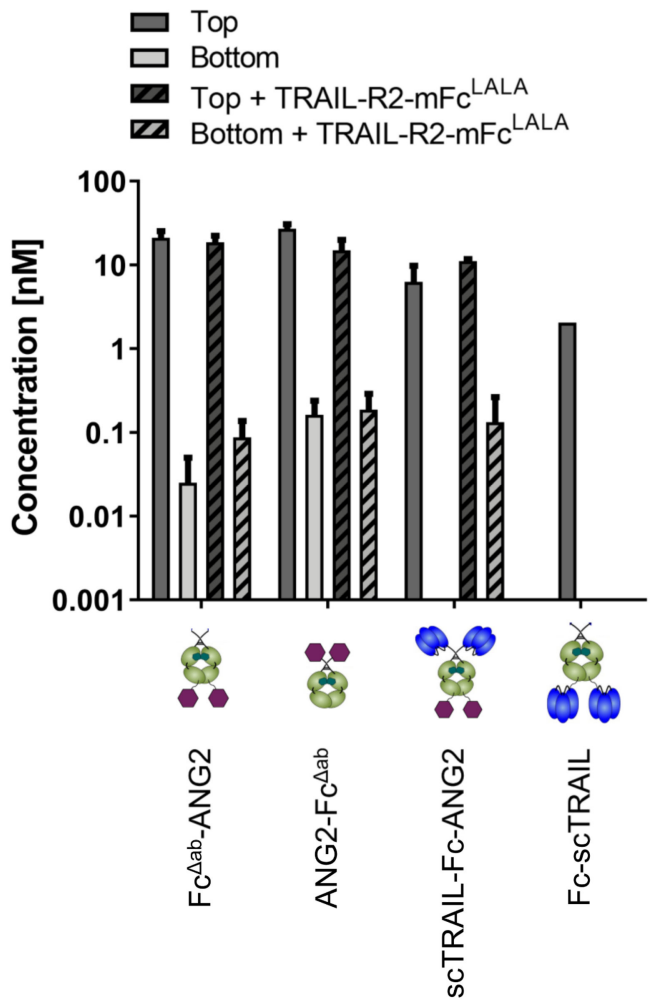

Figure 5. Transwell assay for determination of CNS-transport efficiency (A). bEnd.3 cells were grown to a confluent monolayer on a transwell insert and then $20 \mathrm{nM}$ of indicated construct, with or without 30 min pre-incubation of 100 -fold molar excess of TRAIL-R2-mFc ${ }^{\text {LALA, }}$, was added to the apical compartment. (B) After $60 \mathrm{~min}$ incubation at $37^{\circ} \mathrm{C}$, the samples were taken from the top and bottom compartment of the transwell and the concentration was determined through quantitative sandwich ELISA. Data points are mean + range from two independent experiments. 


\section{Discussion}

TRAIL-based therapeutics have shown great potential in pre-clinical studies as a novel approach for the treatment of GBM [45-47] but the BBB prevents the entry of TRAIL-based biologics from effectively reaching GBM tumours. In this paper, we demonstrate that ANG2-functionalised hexavalent TRAIL receptor agonists retain their potency in killing GBM cells, that BBB endothelial cells are resistant to TRAIL and able to transport large ANG2-based fusion proteins across the BBB. However, transport of ANG2-TRAIL fusion proteins is only possible when the TRAIL binding to BBB endothelial cells is blocked.

Previously, it was demonstrated that TRAIL receptor agonists have broad efficacy against GBM cells alone or in combination with sensitisers [35,45-49]. Beyond GBM, the CNS is also a frequent secondary site for many cancer metastases, including lung cancer, breast cancer and melanoma, consequently leading to lower treatment responses and poor patient outcomes $[50,51]$. Therefore, a CNS-targeted therapeutic variant of TRAIL, which shows broad anti-cancer efficacy in various cancer types $[15,16,52,53]$ would be of considerable clinical interest as an anti-cancer agent. Furthermore, recent studies have suggested that endogenous TRAIL plays an important role in immune modulation in multiple sclerosis [54], suggesting a CNS-targeted TRAIL variant could also be used in the treatment of multiple sclerosis and other inflammatory CNS disorders $[55,56]$. Taken together, this demonstrates that a CNS-targeted therapeutic variant of TRAIL would have broad therapeutic potential and is of considerable clinical interest.

The clinical deployment of TRAIL variants for CNS disease is greatly impeded by the poor penetration of large molecular drugs into the CNS [17]. We took advantage of a widely exploited mechanism for the delivery of therapeutics across the blood-brain barrier by targeting the transport pathway of receptor-mediated transcytosis $[21,57,58]$. Whilst a number of RMT-inducing candidates have been described, we deployed the small peptide ANG2 to increase CNS-penetration of TRAIL variants due to its established efficacy [26,31,43], safety in patients [59], broad species specificity and ease of inclusion of a 19 amino acid peptide within fusion proteins, which makes it an optimal choice for such an exploratory study. In initial apoptosis studies, we demonstrated that the addition of ANG2 maintained the potency of hexavalent TRAIL in inducing apoptosis within the GBM cells, as determined by Annexin V-PI staining and efficient cleavage of the key apoptotic regulators, pro-caspase 8, pro-caspase 3 and PARP. Similar to previous studies, the higher clustering potential of hexavalent scTRAIL was strictly necessary for efficient apoptosis induction in GBM cells as this is required for efficient engagement of TRAILR2 [10,12-14]. Importantly, hexavalent TRAIL receptor agonists based on a similar format, ABBV-621, are currently undergoing clinical trials (NCT03082209). Thus, hexavalent TRAIL could serve as a promising therapeutic agent in the treatment of GBM patients. In contrast to cancer cells, BBB endothelial cells were largely resistant to hexavalent TRAIL receptor agonists even at high concentrations, in accordance with the concept that TRAIL-mediated apoptosis occurs almost exclusively in cancer cells $[6,60]$. We demonstrated that levels of TRAIL receptors in the BBB endothelial cell line hCMEC/D3 were considerably reduced compared to cancer cells. The receptor numbers in these cells were also generally lower than published levels in a wide range of cancer cell lines $[15,16]$. This is in line with previous work demonstrating that endothelial cells do express TRAIL receptors but are resistant to TRAIL-mediated apoptosis [61-63]. Previous studies have also shown that endothelial cells of the BBB are highly resistant to extrinsic apoptosis, due to the activity of the pro-survival factors TAK1 and NEMO [64]. This, together with our findings of low TRAIL-receptor expression, demonstrates that there are multiple factors contributing to high TRAIL resistance in BBB endothelial cells.

Our combined binding data from flow cytometry and immunostaining demonstrated that ANG2-based constructs bind to blood-brain barrier cells. In the transport assay, this was sufficient for the transport of ANG2-only constructs across BBB endothelial cells. We also demonstrated that ANG2 was active within fusion proteins regardless of whether it was fused to the N- or C-terminus of the protein. Whilst other studies of 
ANG2 use C-terminal labelling, our data suggest this is not an absolute requirement for ANG2 function $[36,37]$. Our transport assays were performed using b.End3 cells grown on a transwell insert. We reported a TEER value for this setup of $17 \Omega \cdot \mathrm{cm}^{2}$. Previous TEER values reported for b.End 3 cells vary widely from $15-140 \Omega \cdot \mathrm{cm}^{2}$ [65-67]. Whilst our reported TEER values are on the lower side of this range, they are in line with what was previously reported and we observed no apparent effect from passive diffusion at the time step chosen. Applying this in vitro BBB model, we achieved transport rates of (0.1-0.3 pmoles $\left./ \mathrm{cm}^{2} / \mathrm{h}\right)$. Whilst these are lower than the reported rates for ANG2 crossing bovine brain endothelial cells ( $\sim 6$ pmoles $/ \mathrm{cm}^{2} / \mathrm{h}$ ) [31], this is likely due to the significantly lower concentration of protein added to the apical side in our transwell experiments. Due to the lack of LRP1 expression on hCMEC/D3 cells, we were unable to extend our transport findings to human BBB endothelial cells. Whilst angiopep-2 was shown to be active in different species, including human clinical trials (NCT03613181), further investigation is required to ascertain how these constructs behave in human models $[26,31,36]$.

Our key finding was that the presence of TRAIL interfered with ANG2-mediated transport, despite the expression of TRAIL receptors being low. As binding rates are dictated by individual affinities, receptor availability and avidity effects, this suggests that either the receptor levels of LRP1 are lower than for TRAIL receptors or that TRAIL has a significantly higher binding rate for its receptors than ANG2, potentially due to higher individual affinity or overall avidity. Importantly, recent studies have shown that reduced overall affinity binding is beneficial for efficient RMT, whether by lowering the affinity itself or by reducing the avidity of binding [68-73]. This is apparently due to the redirection of cargo to lysosomal compartments instead of being trafficked across the cell $[69,70,74,75]$. The reported low affinity of ANG2 to its target receptor LRP1, $330 \mathrm{nM}$ [43], suggests that although it was not deliberately engineered as a reduced affinity binder, it operates in such a manner. Indeed, the precursor protein, angiopep-1, shows greater total brain distribution but has greater accumulation within capillary fractions suggesting similar lysosomal sorting occurs for LRP1-mediated transcytosis [31]. Hexavalent TRAIL receptor agonists, on the other hand, bind to cells at sub-nanomolar concentrations, due to the combined high affinity and avidity of the hexavalent agonist $[9,12,76,77]$. This several orders of magnitude higher affinity of TRAIL, together with the expression of TRAIL receptors at BBB endothelial cells, would potentially explain why we found that TRAIL-ANG2 fusion proteins bound BBB endothelial cells in a predominantly TRAIL-mediated manner, consequently resulting in poor transport across the BBB. Whilst such an effect has not been shown in BBB delivery before, similar effects were demonstrated in bispecific anti-tumour therapeutics, where reducing the affinities of one arm alters drug disposition and can improve therapeutic efficiency. This is a particularly important consideration in the development of future therapeutics based on the concept of reduced affinity brain shuttles, the selection of therapeutic targets that do not interfere with BBB endothelial cell binding and transport. Importantly, quantitative proteomics data in isolated brain microvessels have demonstrated that LRP1 is expressed at lower levels when compared to other RMT targets such as the transferrin receptor in both mice and humans [78-80]. The greater levels of receptors for other targets may help to offset the reduced affinity of binding. Alternatively, in the future, an adaptation of the high-affinity TRAIL moiety could be utilised to facilitate better transcytosis. This can be achieved by mutations reducing affinity to the TRAIL receptors or by lowering the avidity with trimeric TRAIL receptor agonists that are selectively clustered in situ at cancer cells. Importantly, various mutations that reduce TRAIL affinity to its receptors were previously reported [81] and enhanced clustering of TRAIL receptors at target cancer cells by dual targeting against epidermal growth factor receptor (EGFR) was also established [12,82] suggesting these could be viable future strategies to reduce TRAIL affinity and therefore increase its CNS-delivery. Alternatively, a TRAIL- or TRAIL-R blocking strategy could be employed either using systemic blocking peptides, as demonstrated in this paper, or by including interfering moieties within the fusion-protein itself that are selectively cleaved off within the CNS, which will then allow the efficient ANG2-mediated transport of TRAIL- 
fusion proteins into the CNS. Overall, our data demonstrate that the high-affinity binding of TRAIL therapeutics interferes with Angiopep-2-mediated across BBB endothelial cells. Our findings emphasise that BBB expression of high-affinity therapeutic targets can interfere with transport processes and is an essential consideration when designing CNS-targeted therapeutics based on reduced affinity RMT.

\section{Materials and Methods}

\subsection{Reagents and Antibodies}

The peptides FITC-ANG2 (FITC-Ahx-TFFYGGSRGKRNNFKTTEEY), FITC-scrANG2 (FITC-Ahx-NSFEGTGGEYFTYRKRNFK) and FLAG-ANG2 (FLAG- TFFYGGSRGKRNNFKTTEEY) were purchased from Peptides and Elephants (Brandenburg, Germany). Hoechst 33342 was obtained from Thermo Fisher Scientific (Waltham, MA, USA). QIFIKIT was obtained from Dako (K0078, Glostrup, Denmark). Annexin V-EGFP was produced in-house. PI was obtained from Sigma Aldrich (Munich, Germany). For flow cytometry, the following antibodies were used: primary antibodies: mouse anti-TRAILR1/TNFRSF10A (MAB347, 1:100), mouse anti-TRAILR2/TNFRSF10B (MAB6311, 1:100), mouse anti-TRAILR3/TNFRSF10C (MAB6302, 1:100), mouse anti-TRAILR4/TNFRSF10D (MAB633, 1:100), purified mouse IgG1 (1:100) and purified mouse IgG2b (1:100), purchased from R\&D Systems (Wiesbaden-Nordenstadt, Germany). Secondary antibodies: anti-FLAG-PE (130-101-577, 1:200, Miltenyi Biotec, Bergisch Gladbach, Germany), goat anti-mouse FITC (F0479, 1:50, Dako, Glostrup, Denmark). Anti-FLAG M2 affinity gel (A2220, Sigma-Aldrich, Munich, Germany), FLAG peptide (EPO174, Peptides and Elephants, Brandenburg, Germany) were used for protein purification. The antibodies used for immunocytochemistry were, primary antibodies: anti-FLAG rabbit (F7425, 1:100, Merck KGaA (Darmstadt, Germany), anti-FC-PE (109-115-098, 1:50, Jackson ImmunoResearch, Cambridgeshire, UK). Secondary antibodies: goat anti-rabbit 131 Alexa Flour 647 IgG (H + L) (A-21245), goat anti-mouse Alexa 132488 IgG (H + L) (A-11029), goat anti-rabbit Alexa 488 IgG $133(\mathrm{H}+\mathrm{L})(\mathrm{A}-11008)$, all purchased from Thermo Fisher Scientific (Waltham, MA, USA). The following antibodies were used for western blotting: mouse caspase 8 (IC12), rabbit caspase 8 (D35G2), rabbit procaspase 3 (9662), rabbit PARP (9542) mouse $\alpha$-tubulin (DM1A), rabbit $\beta$-actin (4967), all purchased from Cell Signaling Technology (Danvers, MA, USA) and mouse PARP (4C10-5) from BioLegend (San Diego, CA, USA). For ELISA, the following antibodies were used, goat human IgG (Fc) specific-alkaline phosphatase from Sigma-Aldrich (Munich, Germany), mouse IgG $(\mathrm{Fc})$ CH2 Domain- HRP from Bio-Rad Antibodies (Hercules, CA, USA).

\subsection{Generation of Constructs}

The plasmid pSecTagA-scTRAIL(281-G118)-(GGSGG)4-Fc was used for the generation of scTRAIL-Fc-ANG2 and sc-TRAIL-ANG2, which were obtained by PCR with respective primers and then digested with restriction enzymes Age1, EcoR1 and cloned into pSecTag-AL1 vector to obtain pSecTagAL1-Flag-scTRAIL-Fc-ANG2 and pSecTagAL1FLAG-scTRAIL-ANG2. For the generation of mutant $\mathrm{Fc}^{\Delta \mathrm{ab}}$-ANG2 plasmids, $\mathrm{Fc} \Delta \mathrm{ab}$ was cut from pAB1-L1-Dbhu225x3-43-CH1-Fc $\Delta$ ab and then cloned into pSecTag-AL1 with respective primers to obtain pSecTagAL1-Fc $\Delta$ ab-Angiopep2 and pSecTagAL1-Angiopep2Fc $\Delta \mathrm{ab}$. The TRAIL-R2-Fc was cloned using the extracellular domain of TRAIL-R2 and produced as previously described [83]. The TRAIL-R2-mFc ${ }^{\text {LALA }}$ was cloned using the extracellular domain of TRAIL-R2 and fused with the primers to murine $\mathrm{Fc}_{\mathrm{C}}$ part containing the PGLALA-mutation vector. $5^{\prime}-$

The following primers were used for the generation of constructs: scTRAIL-Fc-ANG2:

TTTGAATTCTCAGTATTCTTCCGTCTTAAAATTGTTCCTCTTGCCCCTAGACCCACCGT AGAAAAAAGTAGAACCGCCTCCTCCACCTGATCCGCCACCTCCTTTACCCGGAGAC AGGG-3' (forward), 5' -AAAACCGGTGACTACAAAGACG-3' (backward); scTRAIL-ANG2: $5^{\prime}$ - 
TTTGAATTCTCAGTATTCTTCCGTCTTAAAATTGTTCCTCTTGCCCCTAGACCCACCGT AGAAAAAAGTGCCGCCAGATCCGCC-3' (forward), $5^{\prime}-$ AAAACCGGTGACTACAAAGACG-3' (backward); Fc ${ }^{\Delta a b}$-ANG2: 5' -

TTTTTGAATTCTCAGTATTCTTCCGTCTTAAAATTGTTCCTCTTGCCCCTAGACCCACC GTAGAAAAAAGTAGATCCACCGCCACCTGATCCGCCACCTCCTTTGCCGGGGGACA GGC-3' (forward), 5'-AAAAAACCGGTGACAAGACCCACACCTGTC-3' (backward), ANG2-Fc ${ }^{\Delta \mathrm{ab}}: 5^{\prime}$-TTTTTGAATTCTTATTTGCCGGGGG-3' (forward), 5'-

AAAAAACCGGTACTTTTTTCTACGGTGGGTCTAGGGGCAAGAGGAACAATTTTAAG ACGGAAGAATACGGAGGTGGCGGATCAGGTGGCGGTGGATCTGACAAGACCCACA CCTGTC-3' (backward); TRAIL-R2-mFc ${ }^{\text {LALA }}$ : 5'-

TTTTGAAGACCCCTCCTGAGAGAGAACAGGGAGAG-3' (forward), $5^{\prime}$ AAAAGAAGACGGACCGGTGAGTCTGCTCTGATCACCC-3' (backward).

\subsection{Production and Purification of the Recombinant Proteins}

TRAIL constructs were produced in HEK293-6E cells with TRAIL-R2 knockout, and transfected cells were cultured in F17 medium (A1383503, Thermo Fischer Scientific, Waltham, MA, USA) supplemented with $50 \mu \mathrm{M} \mathrm{ZnCl}_{2}$ and tryptophan (TN1, Organotechnie S.A.S., La Courneuve, France). Later, the supernatants were collected and incubated with anti-FLAG M2 affinity gel overnight on a roller mixer at $4{ }^{\circ} \mathrm{C}$. After washing the column with $1 x$ TBS, the beads were added and eluted with $100 \mu \mathrm{g} / \mathrm{mL}$ FLAG peptide. For Fc fusion ANG2, TRAIL-R2-Fc, TRAIL-R2-mFc ${ }^{\text {LALA }}$ constructs, the transfection was carried out in HEK293 cells cultured in F17 medium. The supernatants were incubated with protein A Sepharose beads overnight on a roller mixer at $4{ }^{\circ} \mathrm{C}$ and the elution was carried out with protein A elution buffer (Glycine- $\mathrm{HCl} \mathrm{pH}$ 3.5). For all proteins produced, dialysis was carried out overnight in 1x PBS and proteins were concentrated with Vivaspin 20 centrifugal concentrators (VS2001/VS2031, Sartorius, Göttingen, Germany). Protein concentrations were measured using a Nanodrop instrument (Thermo Fischer Scientific, Waltham, MA, USA), based on calculated molecular weights and extinction coefficients. As a further purification step, size exclusion fast protein liquid chromatography was performed using Superdex 200 10/300 GL column (PBS as mobile phase, flow rate of $0.5 \mathrm{~mL} / \mathrm{min}$ ). Subsequently, produced proteins were analysed by SDS page and HPLC size exclusion chromatography using Phenomenex Yarra $3 \mu \mathrm{m}$ SEC-2000 or -3000 column (00H-4512-K0 or 00H-4513-K0, Phenomenex, CA, USA), a Waters 2695 HPLC, and a mobile phase consisting of $0.1 \mathrm{~mol} / \mathrm{L} \mathrm{Na}_{2} \mathrm{HPO}_{4} / \mathrm{NaH}_{2} \mathrm{PO}_{4}, 0.1 \mathrm{~mol} / \mathrm{L} \mathrm{Na}_{2} \mathrm{SO}_{4}, \mathrm{pH} 6.7$ at a flow rate of $0.5 \mathrm{~mL} / \mathrm{min}$.

\subsection{Cell Culture}

The cell lines A172, bEnd.3 and HCT116 were obtained from ATCC (Manassas, WV, USA), HEK293-6E from National Research Council of Canada (Ottawa, ON, Canada), hCMEC/D3 from Merck Millipore (Darmstadt, Germany), MEF WT from Institute of Cell Biology and Immunology (kindly provided by Dr. rer. nat. Kornelia Ellwanger). The cells were grown as per supplier's instructions. The hCMEC/D3 cells were grown in Endothelial Cell Growth medium MV with supplements including $0.05 \mathrm{~mL} / \mathrm{mL}$ of Fetal Calf Serum, $0.004 \mathrm{~mL} / \mathrm{mL}$ of Endothelial Cell Growth Supplement, $10 \mathrm{ng} / \mathrm{mL}$ of Epidermal Growth Factor, $90 \mu \mathrm{g} / \mathrm{mL}$ of Heparin, $1 \mu \mathrm{g} / \mathrm{mL}$ of Hydrocortisone and $1 \mathrm{ng} / \mathrm{mL}$ of basic Fibroblast Growth Factor (C-39221, Promo cell, Heidelberg, Germany). The flasks were coated with $10 \mu \mathrm{g} \mathrm{cm}^{-2}$ Rat Tail Collagen I (A10483-01, Thermo Fischer Scientific, Waltham, MA, USA) in PBS for $1 \mathrm{~h}$ at $37^{\circ} \mathrm{C}$. The bEnd.3, A172 cells were cultured in DMEM (41965-039, Thermo Fischer Scientific, Waltham, MA, USA) and HCT116 were cultured in RPMI (21875-034, Thermo Fischer Scientific, Waltham, MA, USA) with 10\% FCS (P30-3302, PAN Biotech, 
Aidenbach, Germany). All cells were maintained in a humidified incubator at $37^{\circ} \mathrm{C}$ with $5 \% \mathrm{CO}_{2}$. All cell lines were tested for absence of mycoplasma infection.

\subsection{Receptor Quantification}

For quantifying cell surface receptors, cells were harvested (100,000 cells/well) and resuspended in cold PBA [1x PBS, 0.05\% BSA (Bio\&Sell, Feucht, Bavaria, Germany) and $0.02 \%$ Sodium Azide (422.1, Carl Roth, Karlsruhe, Germany)]. Then the cells were incubated in primary antibody for $1 \mathrm{~h}$ on ice, followed by washing with PBA and incubation with secondary antibody for $1 \mathrm{~h}$ on ice. Subsequently, the cells were washed with PBA and measured using a MACSQuant analyser 10 flow cytometer against DAKO QIFIKIT beads as per manufacturer's instructions. IgG1 (anti-TRAILR1, anti-TRAILR3, anti-TRAILR4) and IgG2b (anti-TRAILR2) were used as isotype controls.

\subsection{Cell Binding Assays}

Cells (50,000 cells / well) were harvested and resuspended in cold PBA (1xPBS, $0.05 \%$ BSA and $0.02 \%$ Sodium Azide). The cells were incubated with different constructs in serial dilution for $2 \mathrm{~h}$ on ice. For blocking experiments, cells were pre-incubated for $30 \mathrm{~min}$ with constructs in which the TRAIL moieties were blocked with TRAIL-R2-Fc or TRAIL-R2$\mathrm{mFc}^{\mathrm{LALA}}$. After incubation, cells were washed with PBA and incubated for $2 \mathrm{~h}$ with the secondary antibody depending on the detection moiety of the constructs. The binding was measured by flow cytometry and the median fluorescence intensities were obtained for each construct. For display purposes, we normalised FITC-ANG2 and FITC-scrANG2 binding intensity to the lowest concentration of scrANG2.

\subsection{Cell Death Assays}

Cells were grown in 96-well flat-bottom plates for $24 \mathrm{~h}$ and incubated with the constructs in serial dilution. After $24 \mathrm{~h}$, floating cells were collected while adherent cells were collected by trypsinisation with trypsin/EDTA (Thermo Fischer Scientific, Waltham, MA, USA) and stained with Annexin V/PI for $10 \mathrm{~min}$ at room temperature. For hCMEC/D3 and A172 cells, cell death was measured by flow cytometry. The percentage of living cells was defined as the percentage of $\mathrm{AnV}^{-} \mathrm{PI}^{-}$cells normalised against untreated control cells.

\subsection{Crystal Violet Assay}

10,000 cells/well were seeded in $100 \mu \mathrm{L}$ medium in 96-well plate (F bottom) and grown for $24 \mathrm{~h}$ at $37^{\circ} \mathrm{C}, 5 \% \mathrm{CO}_{2}$. A total of $200 \mu \mathrm{L}$ of serial diluted proteins were added to the cells and were incubated for $16 \mathrm{~h}$ at $37^{\circ} \mathrm{C}, 5 \% \mathrm{CO}_{2}$. After incubation for $16 \mathrm{~h}$, the cells were washed with PBS and $50 \mu \mathrm{L} /$ well of crystal violet staining solution was added and incubated for $15 \mathrm{~min}$ at RT. Staining was removed and the cells were left to dry overnight at RT. A total of $100 \mu \mathrm{L}$ of methanol was added per well and the absorption was measured at $570 \mathrm{~nm}$ on a microplate reader (SPARK, Tecan, Männedorf, Switzerland).

\subsection{Mass Spectrometry}

scTRAIL-Fc-ANG2 was loaded on Bolt 4-12\% Bis-Tris Plus pre-cast gels and was run in a Bolt Mini tank with Bolt MES SDS running buffer purchased from Thermo Fischer Scientific (Waltham, MA, USA). The gel was washed with Milli-Q water to remove the buffer and then stained with instant Coomassie blue (11022018, Expedeon, Heidelberg, Germany). After staining, the gel was again washed with Milli-Q water. The stained protein bands were cut, washed with Milli-Q water and then centrifuged for $1 \mathrm{~min}$ at 11,000 rpm. To the gel pieces, $200 \mu \mathrm{L}$ of $50 \mathrm{mM} \mathrm{NH}_{4} \mathrm{HCO}_{3}$ (09830-500G, Sigma Aldrich, Munich, Germany) and 100\% acetonitrile (4722.1, Carl Roth, Karlsruhe, Germany) $1+1(v / v)$ was added and incubated in the shaker for $15 \mathrm{~min}$. The solution was discarded and the gel was incubated with $50 \mu \mathrm{L}$ of $100 \%$ acetonitrile for $5 \mathrm{~min}$ for dehydration. Once the gel was shrunk, acetonitrile was removed and $50 \mathrm{mM}$ of $\mathrm{NH}_{4} \mathrm{HCO}_{3}$ was added to the gel and incubated for $5 \mathrm{~min}$ for rehydration. Then an equal volume of acetonitrile was added and 
incubated for $15 \mathrm{~min}$ while shaking. The remaining solution was removed and the gel was air-dried in a vacuum centrifuge. For the in-gel digestion, the air-dried gel particle was digested with a solution of $5 \mathrm{ng} / \mathrm{mL}$ Trypsin (sequencing grade modified Trypsin, Promega, Walldorf, Germany), $50 \mathrm{mM} \mathrm{NH}_{4} \mathrm{HCO}_{3}$ and $100 \%$ acetonitrile and incubated overnight at $37^{\circ} \mathrm{C}$. The supernatant was removed and $25 \mu \mathrm{L}$ of TA20 $(20 \%$ acetonitrile and $0.1 \%$ of Trifluoroacetic acid, TFA (P088.2, Carl Roth, Karlsruhe, Germany) was added. The gel particles were ultrasonicated (USR32H, Merck eurolab, Lutterworth, UK) for $5 \mathrm{~min}$ and incubated for $30 \mathrm{~min}$. The supernatant was collected and the steps were repeated with TA50 ( $50 \%$ acetonitrile and $0.1 \%$ of TFA). The supernatants were combined and dried for $1 \mathrm{~h}$ in a vacuum centrifuge. The dried pellet was dissolved in $10 \mu \mathrm{L}$ of $0.1 \%$ TFA. A $1 \mu \mathrm{L}$ of the sample was added to the MALDI target plate (MTP Anchor Chip 384TF, Bruker Daltronics, Billerica, MA, USA). After drying $1 \mu \mathrm{L}$ of Matrix solution $(0.7 \mathrm{mg} / \mathrm{mL}$ a-Cyano-4-hydroxycinnamic acid (39468-10x10MG, Sigma Aldrich, Munich, Germany) was dissolved in a solvent mixture containing $85 \%$ acetonitrile, $15 \% \mathrm{H}_{2} \mathrm{O}, 0,1 \%$ TFA and $1 \mathrm{mM} \mathrm{NH}_{4} \mathrm{H}_{2} \mathrm{PO}_{4}$ was spotted above the sample. For peptide calibration $0.5 \mu \mathrm{L}$ Peptide Calibration Standard II (222570, Bruker Daltronics, Billerica, MA, USA) was spotted on the same target plate. The plate was inserted in the MALDI-TOF machine (Bruker ${ }^{\mathrm{TM}}$ Autoflex Speed MALDI TOF, Billerica, MA, USA) and the samples were analysed using (Flex Control and Flex Analysis) software.

\subsection{Immunocytochemistry}

Cells were grown on coverslips coated with $2.5 \mu \mathrm{g} / \mathrm{mL}$ Collagen R solution (08-115, Sigma-Aldrich, Munich, Germany). Once the cells were confluent, they were incubated with the constructs for different times at $37^{\circ} \mathrm{C}$. After the incubation, cells were washed with PBS and fixed with 4\% paraformaldehyde (sc-281692, Santa Cruz Biotechnology Inc., Santa Cruz, CA, USA) for $30 \mathrm{~min}$. Thereafter, cells were permeabilised with Triton X-100 in PBS for 10 min and blocked with $4 \%$ BSA. The cells were incubated with primary antibodies for $1 \mathrm{~h}$ at RT and diluted in PBS followed by washing and incubation with $4 \mu \mathrm{g} / \mathrm{mL}$ secondary antibodies for $45 \mathrm{~min}$ at RT. After washing, cells were mounted with Fluoromount-G. Images were acquired on a confocal laser scanning microscope (LSM 710, Carl Zeiss, Oberkochen, Germany) equipped with a Plan-Apochromat 63x/1.4 Oil objective. DAPI was excited with a $405 \mathrm{~nm}$ diode laser, its emission was detected from 410-490 nm. PE was excited with a $561 \mathrm{~nm}$ DPSS laser, its emission was detected from 553-660 nm. All images were subjected to identical post-imaging processing for comparability, including linear adjustments to brightness/contrast and maximum intensity projections using the ZEN black software version 2.1 (Carl Zeiss). Images were quantified using CellProfiler version 3.1.8 [84]. In brief, cells were segmented and speckles in the PE channel under the cell mask were counted. Additionally, the mean intensity in the red channel was measured for each cell.

\subsection{Western Blotting}

For protein extraction, the cell pellets were resuspended in lysis buffer and incubated for $15 \mathrm{~min}$ on ice, then the samples were centrifuged for $15 \mathrm{~min}$ at 16,000 $\mathrm{g}$ and the supernatant was transferred to new reaction tubes. Protein concentrations were quantified by Bradford assay. The protein concentration was calculated and then prepared with ddH2O and $5 x$ loading buffer with a final concentration of $1-2 \mu \mathrm{g} / \mu \mathrm{L}$ protein. The samples were incubated for $5 \mathrm{~min}$ at $95{ }^{\circ} \mathrm{C}$ on a heat block (HBT-1-131, Haep Labor Consult, Bovenden, Germany) and frozen at $-20^{\circ} \mathrm{C}$. For the SDS PAGE, the samples and the molecular weight marker were loaded into Bolt $4-12 \%$ Bis-Tris Plus Gel $1.0 \mathrm{~mm} \times 15$ well or Bolt $4-12 \%$ Bis-Tris Plus Gel $1.0 \mathrm{~mm} \times 17$ well with Bolt MES SDS Running Buffer (20X) placed on Bolt Mini Gel Tank chamber (Thermo Fisher Scientific). The proteins were separated in the gel at $150 \mathrm{~V}$ for about $40 \mathrm{~min}$. The separated proteins were transferred to a nitrocellulose membrane using the iBlot 2 Dry Blotting System (transfer settings: $20 \mathrm{~V}$; $7 \mathrm{~min}$, Thermo Fisher Scientific Inc.). The membranes were washed and incubated for at 
least $1 \mathrm{~h}$ with blocking reagent (diluted 1:10 in TBST, Roche Diagnostics, Basel, Elveția) washed three times with TBST for $10 \mathrm{~min}$ and incubated with the primary antibody (diluted in TBST with blocking reagent $(1: 20)$ and $0.02 \%(w / v) \mathrm{NaN} 3))$ overnight at $4{ }^{\circ} \mathrm{C}$ or for $1 \mathrm{~h}$ at RT. After three more washing steps with TBST, membranes were incubated with a horseradish peroxidase (HRP) coupled secondary antibody (diluted in TBST with blocking reagent $(1: 20) 1 \mathrm{~h}$ at RT. The membranes were washed and prepared for detection. For the detection process, the membranes were incubated with an HRP substrate (SuperSignal West Pico ECL Substrate/SuperSignal West Dura Extended, Pierce Protein Research Products; Luminata Forte Western HRP Substrate from Merck Millipore (Darmstadt, Germany) and detected with Amersham ${ }^{\mathrm{TM}}$ Imager 600 (GE Healthcare Bio-Sciences, Pittsburgh, PA, USA).

\subsection{MTT Assay}

bEnd. 3 cells seeded in a 96-well plate (F bottom) and let to attach and grow for $24 \mathrm{~h}$. Then, the cells were treated with scTRAIL-Fc-ANG2, scTRAIL-ANG2 and IZI1551 in serial dilution for $24 \mathrm{~h}$. After the treatment, $20 \mu \mathrm{L}$ of MTT solution $(5 \mathrm{mg} / \mathrm{mL})$ were added to each well including the wells without cells. The plate was incubated for $3-4 \mathrm{~h}$ in the incubator at $37^{\circ} \mathrm{C}$. Later, the medium was aspirated and $200 \mu \mathrm{L}$ of methanol was added to each well and incubated for $10 \mathrm{~min}$ in the incubator. The absorbance was measured at a wavelength of $570 \mathrm{~nm}$ with a Tecan plate reader (Infinite M200 or SPARK, Tecan, Meannedorf, Switzerland).

\subsection{Blood-Brain Barrier Transwell Setup and Transport Assay}

The bEnd. 3 cells ( 30,000 cells / well), were seeded in 24-well transwell plate $\left(0.33 \mathrm{~cm}^{2}\right.$ surface area, $0.4 \mu \mathrm{m}$ pore size, Sigma-Aldrich, St. Luis, MO, USA) with their respective medium. Transendothelial electrical resistance (TEER) was measured every day for 6-7 days using EVOM 2/STX2 electrode (World Precision Instruments, Sarasota, FL, USA) to check the integrity of barrier cells. The medium was changed once in two days. Two negative controls without the cells were maintained to subtract from the resistance of the samples. Once a stable TEER value was reached (plateaued for 3 consecutive days), the cells were prepared for the transport experiment. The cells were preincubated for $1 \mathrm{~h}$ with $50 \mu \mathrm{M}$ QVD diluted in medium. After that, the cells were washed with sterile PBS. A total of $20 \mathrm{nM}$ of $\mathrm{Fc}^{\Delta \mathrm{ab}}$-ANG2, ANG2-Fc ${ }^{\Delta \mathrm{ab}}$, scTRAIL-Fc-ANG2 and Fc-scTRAIL diluted in BSA $(2 \%)$ were added to the wells with cells and incubated at $37^{\circ} \mathrm{C}$. After $1 \mathrm{~h}$, the samples from the top and bottom were taken and were measured using ELISA. The time point of $1 \mathrm{~h}$ was used to allow efficient detection of basolateral protein as determined in a pre-experiment. The top well samples were diluted 1:20 for the measurement.

\subsection{ELISA for the Transport Measurement}

The ELISA plates from Greiner Bio-One (Frickenhausen, Germany) were coated with anti-human IgG $(\mathrm{Fc})$ diluted (1:1000) in ELISA coating buffer and left overnight at $4{ }^{\circ} \mathrm{C}$. The next day, ELISA plates were washed with ELISA washing buffer three times and blocked with $2 \%$ BSA in PBS for $1 \mathrm{~h}$. Plates were washed with washing buffer five times. A total of $100 \mu \mathrm{L}$ of the samples from the transwell and also the samples for the standard were added to the ELISA plate and incubated for $2 \mathrm{~h}$ at RT. The plates were again washed with washing buffer five times. The plates were incubated with the detection antibody anti-human IgG $(\mathrm{Fc}) \mathrm{CH} 2$ Domain: HRP diluted (1:500) in 2\% BSA for $2 \mathrm{~h}$ at RT. The plates were washed seven times with washing buffer and then incubated with TMB substrate for 5 to $10 \mathrm{~min}$. After that, to stop the reaction, the ELISA stop solution was added. A standard curve was established for each construct and the transported proteins in the transwell were determined by interpolation from the standard curve and under consideration of the dilution factor. The absorbance was measured at a wavelength of $450 \mathrm{~nm}$ with a Tecan plate reader (Infinite M200 or SPARK, Tecan, Meannedorf, Switzerland). 


\subsection{Statistics}

GraphPad Prism 7 (GraphPad Software, San Diego, CA, USA) was used to analyse all data. Statistical significance of difference between groups was performed by indicated significance test. Parametric tests were performed only after confirming normal distribution of the data using the D'Agostino and Pearson omnibus normality test. For receptor quantification, statistical analysis was performed on log-transformed values, after verification of log-normal distribution by D'Agostino and Pearson omnibus test. Significance levels were denoted with asterisks: ${ }^{*}=p \leq 0.05{ }^{* *}=p \leq 0.01 ;{ }^{* * *}=p \leq 0.001^{* * * *}=p \leq 0.0001$.

Supplementary Materials: The following are available online, Figures S1-S4 and uncropped images of all blots.

Author Contributions: Conceptualization, N.K.M., O.S., R.E.K., M.R. and G.F.; Formal analysis, N.K.M., S.E., S.W. and G.F.; Funding acquisition, R.E.K., M.R. and G.F.; Investigation, N.K.M. and S.W.; Methodology, N.K.M. and O.S.; Supervision, M.R. and G.F.; Writing—original draft, N.K.M., M.R. and G.F.; Writing-review and editing, O.S. and R.E.K. All authors have read and agreed to the published version of the manuscript.

Funding: M.R., N.K. and G.F. are funded by the European Union's Horizon 2020 research and innovation programme (grant agreement \#766069 (GLIO-TRAIN)). M.R., G.F. and R.E.K. receive further support from the BMBF (Federal Ministry of Education and Research) through the collaborative project BrainAim (16GW0326). M.R. receives support from the German Research Foundation (DFG FOR2036 MO 3226/1-1; EXC 2075 390740016; MO 3226/4-1).

Institutional Review Board Statement: Not applicable.

Informed Consent Statement: Not applicable.

Data Availability Statement: All processed data for the study are included within the manuscript and Supplementary Materials. Raw datasets are available from the corresponding author on reasonable request.

Acknowledgments: We would like to thank Albert Jeltsch for kindly letting us use the mass spectrometry facility. We thank Martin Siegemund for useful discussions on cloning strategies and Doris Göttsch for technical assistance.

Conflicts of Interest: R.E.K. and O.S. are named inventors on patents covering the TRAIL technology. All other authors declare no conflict of interest. The funders had no role in the design of the study; in the collection, analyses, or interpretation of data; in the writing of the manuscript, or in the decision to publish the results.

\section{References}

1. Louis, D.N.; Ohgaki, H.; Wiestler, O.D.; Cavenee, W.K.; Burger, P.C.; Jouvet, A.; Scheithauer, B.W.; Kleihues, P. The 2007 WHO Classification of Tumours of the Central Nervous System. Acta Neuropathol. 2007, 114, 97-109. [CrossRef]

2. Ostrom, Q.T.; Cioffi, G.; Gittleman, H.; Patil, N.; Waite, K.; Kruchko, C.; Barnholtz-Sloan, J.S. CBTRUS Statistical Report: Primary Brain and Other Central Nervous System Tumors Diagnosed in the United States in 2012-2016. Neuro-Oncology 2019, 21, v1-v100. [CrossRef]

3. Stupp, R.; Mason, W.P.; van den Bent, M.J.; Weller, M.; Fisher, B.; Taphoorn, M.J.; Belanger, K.; Brandes, A.A.; Marosi, C.; Bogdahn, U.; et al. Radiotherapy plus Concomitant and Adjuvant Temozolomide for Glioblastoma. N. Engl. J. Med. 2005, 352, 987-996. [CrossRef]

4. Koshy, M.; Villano, J.L.; Dolecek, T.A.; Howard, A.; Mahmood, U.; Chmura, S.J; Weichselbaum, R.R.; McCarthy, B.J. Improved survival time trends for glioblastoma using the SEER 17 population-based registries. J. Neuro-Oncol. 2011, 107, 207-212. [CrossRef]

5. Tran, B.; Rosenthal, M. Survival comparison between glioblastoma multiforme and other incurable cancers. J. Clin. Neurosci. 2010, 17, 417-421. [CrossRef] [PubMed]

6. Walczak, H.; Miller, R.E.; Ariail, K.; Gliniak, B.; Griffith, T.S.; Kubin, M.; Chin, W.; Jones, J.; Woodward, A.; Le, T.; et al. Tumoricidal activity of tumor necrosis factor-related apoptosis-inducing ligand in vivo. Nat. Med. 1999, 5, 157-163. [CrossRef]

7. Wang, S.; El-Deiry, W.S. TRAIL and apoptosis induction by TNF-family death receptors. Oncogene 2003, 22, 8628-8633. [CrossRef]

8. Johnstone, R.W.; Frew, A.J.; Smyth, M. The TRAIL apoptotic pathway in cancer onset, progression and therapy. Nat. Rev. Cancer 2008, 8, 782-798. [CrossRef] 
9. Gieffers, C.; Kluge, M.; Merz, C.; Sykora, J.; Thiemann, M.; Schaal, R.; Fischer, C.; Branschädel, M.; Abhari, B.A.; Hohenberger, P.; et al. APG350 Induces Superior Clustering of TRAIL Receptors and Shows Therapeutic Antitumor Efficacy Independent of Cross-Linking via Fc $\gamma$ Receptors. Mol. Cancer Ther. 2013, 12, 2735-2747. [CrossRef] [PubMed]

10. De Miguel, D.; Lemke, J.; Anel, A.; Walczak, H.; Martinez-Lostao, L. Onto better TRAILs for cancer treatment. Cell Death Differ. 2016, 23, 733-747. [CrossRef] [PubMed]

11. Wajant, H. Molecular Mode of Action of TRAIL Receptor Agonists-Common Principles and Their Translational Exploitation. Cancers 2019, 11, 954. [CrossRef]

12. Siegemund, M.; Pollak, N.; Seifert, O.; Wahl, K.; Hanak, K.; Vogel, A.; Nussler, A.K.; Göttsch, D.; Münkel, S.; Bantel, H.; et al. Superior antitumoral activity of dimerized targeted single-chain TRAIL fusion proteins under retention of tumor selectivity. Cell Death Dis. 2012, 3, e295. [CrossRef]

13. Hutt, M.; Marquardt, L.; Seifert, O.; Siegemund, M.; Kulms, D.; Kontermann, R.E.; Müller, I.; Pfizenmaier, K. Superior Properties of Fc-comprising scTRAIL Fusion Proteins. Mol. Cancer Ther. 2017, 16, 2792-2802. [CrossRef] [PubMed]

14. Ratain, M.J.; Doi, T.; De Jonge, M.J.; Lorusso, P.; Dunbar, M.; Chiney, M.; Motwani, M.; Glasgow, J.; Petrich, A.M.; Rasco, D.W.; et al. Phase 1, first-in-human study of TRAIL receptor agonist fusion protein ABBV-621. J. Clin. Oncol. 2019, 37, 3013. [CrossRef]

15. Vetma, V.; Guttà, C.; Peters, N.; Praetorius, C.; Hutt, M.; Seifert, O.; Meier, F.; Kontermann, R.; Kulms, D.; Rehm, M. Convergence of pathway analysis and pattern recognition predicts sensitization to latest generation TRAIL therapeutics by IAP antagonism. Cell Death Differ. 2020, 27, 2417-2432. [CrossRef] [PubMed]

16. Phillips, D.C.; Buchanan, F.G.; Cheng, D.; Solomon, L.R.; Xiao, Y.; Xue, J.; Tahir, S.K.; Smith, M.L.; Zhang, H.; Widomski, D.; et al. Hexavalent TRAIL Fusion Protein Eftozanermin Alfa Optimally Clusters Apoptosis-Inducing TRAIL Receptors to Induce On-Target Antitumor Activity in Solid Tumors. Cancer Res. 2021, 81, 3402-3414. [CrossRef]

17. Pardridge, W.M. The Blood-Brain Barrier: Bottleneck in Brain Drug Development. NeuroRx 2005, 2, 3-14. [CrossRef]

18. Pardridge, W.M. Blood-Brain Barrier and Delivery of Protein and Gene Therapeutics to Brain. Front. Aging Neurosci. 2020, 11, 373. [CrossRef]

19. Boado, R.J.; Hui, E.K.-W.; Lu, J.Z.; Pardridge, W.M. Glycemic Control and Chronic Dosing of Rhesus Monkeys with a Fusion Protein of Iduronidase and a Monoclonal Antibody Against the Human Insulin Receptor. Drug Metab. Dispos. 2012, 40, 2021-2025. [CrossRef]

20. Duffy, K.R.; Pardridge, W.M.; Rosenfeld, R.G. Human blood-brain barrier insulin-like growth factor receptor. Metabolism 1988, 37, 136-140. [CrossRef]

21. Pardridge, W.M.; Eisenberg, J.; Yang, J. Human blood-brain barrier transferrin receptor. Metabolism 1987, 36, 892-895. [CrossRef]

22. Tuma, P.L.; Hubbard, A.L. Transcytosis: Crossing Cellular Barriers. Physiol. Rev. 2003, 83, 871-932. [CrossRef] [PubMed]

23. Pardridge, W. Molecular Trojan horses for blood-brain barrier drug delivery. Curr. Opin. Pharmacol. 2006, 6, 494-500. [CrossRef]

24. Jefferies, W.A.; Brandon, M.R.; Hunt, S.V.; Williams, A.F.; Gatter, K.C.; Mason, D.Y. Transferrin receptor on endothelium of brain capillaries. Nature 1984, 312, 162-163. [CrossRef]

25. Lee, H.J.; Engelhardt, B.; Lesley, J.; Bickel, U.; Pardridge, W.M. Targeting rat anti-mouse transferrin receptor monoclonal antibodies through blood-brain barrier in mouse. J. Pharmacol. Exp. Ther. 2000, 292.

26. Demeule, M.; Currie, J.-C.; Bertrand, Y.; Ché, C.; Nguyen, T.; Régina, A.; Gabathuler, R.; Castaigne, J.-P.; Béliveau, R. Involvement of the low-density lipoprotein receptor-related protein in the transcytosis of the brain delivery vector Angiopep-2. J. Neurochem. 2008, 106, 1534-1544. [CrossRef]

27. Thomas, F.C.; Taskar, K.; Rudraraju, V.; Goda, S.; Thorsheim, H.R.; Gaasch, J.A.; Mittapalli, R.K.; Palmieri, D.; Steeg, P.S.; Lockman, P.R.; et al. Uptake of ANG1005, A Novel Paclitaxel Derivative, Through the Blood-Brain Barrier into Brain and Experimental Brain Metastases of Breast Cancer. Pharm. Res. 2009, 26, 2486-2494. [CrossRef]

28. Demeule, M.; Beaudet, N.; Régina, A.; Besserer-Offroy, E.; Murza, A.; Tétreault, P.; Belleville, K.; Ché, C.; Larocque, A.; Thiot, C.; et al. Conjugation of a brain-penetrant peptide with neurotensin provides antinociceptive properties. J. Clin. Investig. 2014, 124, 1199-1213. [CrossRef]

29. Boado, R.J.; Hui, E.K.-W.; Lu, J.Z.; Pardridge, W.M. CHO cell expression, long-term stability, and primate pharmacokinetics and brain uptake of an IgG-paroxonase-1 fusion protein. Biotechnol. Bioeng. 2010, 108, 186-196. [CrossRef] [PubMed]

30. Yang, A.C.; Stevens, M.Y.; Chen, M.B.; Lee, D.P.; Stähli, D.; Gate, D.; Contrepois, K.; Chen, W.; Iram, T.; Zhang, L.; et al. Physiological blood-brain transport is impaired with age by a shift in transcytosis. Nature 2020, 583, 425-430. [CrossRef]

31. Demeule, M.; Régina, A.; Ché, C.; Poirier, J.; Nguyen, T.; Gabathuler, R.; Castaigne, J.-P.; Béliveau, R. Identification and Design of Peptides as a New Drug Delivery System for the Brain. J. Pharmacol. Exp. Ther. 2007, 324, 1064-1072. [CrossRef]

32. Wei, X.; Zhan, C.; Chen, X.; Hou, J.; Xie, C.; Lu, W. Retro-Inverso Isomer of Angiopep-2: A Stable d-Peptide Ligand Inspires Brain-Targeted Drug Delivery. Mol. Pharm. 2014, 11, 3261-3268. [CrossRef]

33. Huang, S.; Li, J.; Han, L.; Liu, S.; Ma, H.; Huang, R.; Jiang, C. Dual targeting effect of Angiopep-2-modified, DNA-loaded nanoparticles for glioma. Biomaterials 2011, 32, 6832-6838. [CrossRef] [PubMed]

34. Shao, K.; Huang, R.; Li, J.; Han, L.; Ye, L.; Lou, J.; Jiang, C. Angiopep-2 modified PE-PEG based polymeric micelles for amphotericin B delivery targeted to the brain. J. Control. Release 2010, 147, 118-126. [CrossRef] [PubMed]

35. Boccellato, C.; Kolbe, E.; Peters, N.; Juric, V.; Fullstone, G.; Verreault, M.; Idbaih, A.; Lamfers, M.L.M.; Murphy, B.M.; Rehm, M. Marizomib sensitizes primary glioma cells to apoptosis induced by a latest-generation TRAIL receptor agonist. Cell Death Dis. 2021, 12, 647. [CrossRef] 
36. Böckenhoff, A.; Cramer, S.; Wölte, P.; Knieling, S.; Wohlenberg, C.; Gieselmann, V.; Galla, H.-J.; Matzner, U. Comparison of Five Peptide Vectors for Improved Brain Delivery of the Lysosomal Enzyme Arylsulfatase A. J. Neurosci. 2014, 34, 3122-3129. [CrossRef] [PubMed]

37. Ji, X.; Wang, H.; Chen, Y.; Zhou, J.; Liu, Y. Recombinant expressing angiopep-2 fused anti-VEGF single chain Fab (scFab) could cross blood-brain barrier and target glioma. AMB Express 2019, 9, 165. [CrossRef]

38. Armour, K.L.; Clark, M.R.; Hadley, A.G.; Williamson, L.M. Recombinant Human IgG Molecules Lacking Fcgamma Receptor I Binding and Monocyte Triggering Activities. Eur. J. Immunol. 1999, 29, 2613-2624. [CrossRef]

39. Pan, G.; Ni, J.; Wei, Y.-F.; Yu, G.-L.; Gentz, R.; Dixit, V.M. An Antagonist Decoy Receptor and a Death Domain-Containing Receptor for TRAIL. Science 1997, 277, 815-818. [CrossRef]

40. Pan, G.; O'Rourke, K.; Chinnaiyan, A.M.; Gentz, R.; Ebner, R.; Ni, J.; Dixit, V.M. The Receptor for the Cytotoxic Ligand TRAIL. Science 1997, 276, 111-113. [CrossRef]

41. Walczak, H.; Degli-Esposti, M.A.; Johnson, R.S.; Smolak, P.J.; Waugh, J.Y.; Boiani, N.; Timour, M.S.; Gerhart, M.J.; Schooley, K.A.; Smith, C.A.; et al. TRAIL-R2: A novel apoptosis-mediating receptor for TRAIL. EMBO J. 1997, 16, 5386-5397. [CrossRef]

42. Storck, S.; Meister, S.; Nahrath, J.; Meißner, J.N.; Schubert, N.; Di Spiezio, A.; Baches, S.; Vandenbroucke, R.; Bouter, Y.; Prikulis, I.; et al. Endothelial LRP1 transports amyloid- $\beta 1-42$ across the blood-brain barrier. J. Clin. Investig. 2015, 126, 123-136. [CrossRef] [PubMed]

43. Bertrand, Y.; Currie, J.-C.; Demeule, M.; Régina, A.; Ché, C.; Abulrob, A.; Fatehi, D.; Sartelet, H.; Gabathuler, R.; Castaigne, J.-P.; et al. Transport characteristics of a novel peptide platform for CNS therapeutics. J. Cell. Mol. Med. 2010, 14, 2827-2839. [CrossRef]

44. Tian, X.; Leite, D.M.; Scarpa, E.; Nyberg, S.; Fullstone, G.; Forth, J.; Matias, D.; Apriceno, A.; Poma, A.; Duro-Castano, A.; et al. On the shuttling across the blood-brain barrier via tubule formation: Mechanism and cargo avidity bias. Sci. Adv. 2020, 6, eabc4397. [CrossRef]

45. Fulda, S.; Wick, W.; Weller, M.; Debatin, K.-M. Smac agonists sensitize for Apo2L/TRAIL- or anticancer drug-induced apoptosis and induce regression of malignant glioma in vivo. Nat. Med. 2002, 8, 808-815. [CrossRef] [PubMed]

46. Opel, D.; Westhoff, M.-A.; Bender, A.; Braun, V.; Debatin, K.-M.; Fulda, S. Phosphatidylinositol 3-Kinase Inhibition Broadly Sensitizes Glioblastoma Cells to Death Receptor- and Drug-Induced Apoptosis. Cancer Res. 2008, 68, 6271-6280. [CrossRef]

47. Hetschko, H.; Voss, V.; Seifert, V.; Prehn, J.H.M.; Kögel, D. Upregulation of DR5 by proteasome inhibitors potently sensitizes glioma cells to TRAIL-induced apoptosis. FEBS J. 2008, 275, 1925-1936. [CrossRef]

48. Lincoln, F.A.; Imig, D.; Boccellato, C.; Juric, V.; Noonan, J.; Kontermann, R.E.; Allgöwer, F.; Murphy, B.; Rehm, M. Sensitization of glioblastoma cells to TRAIL-induced apoptosis by IAP- and Bcl-2 antagonism. Cell Death Dis. 2018, 9, 1112. [CrossRef]

49. Koessinger, A.L.; Koessinger, D.; Kinch, K.; Martínez-Escardó, L.; Paul, N.R.; Elmasry, Y.; Malviya, G.; Cloix, C.; Campbell, K.J.; Bock, F.J.; et al. Increased Apoptotic Priming of Glioblastoma Enables Therapeutic Targeting by BH3-Mimetics. bioRxiv 2021. [CrossRef]

50. Bagci-Onder, T.; Du, W.; Figueiredo, J.-L.; Martinez-Quintanilla, J.; Shah, K. Targeting breast to brain metastatic tumours with death receptor ligand expressing therapeutic stem cells. Brain 2015, 138, 1710-1721. [CrossRef] [PubMed]

51. Wagner, J.; Kline, C.L.; Zhou, L.; Campbell, K.S.; Macfarlane, A.W.; Olszanski, A.J.; Cai, K.Q.; Hensley, H.H.; Ross, E.A.; Ralff, M.D.; et al. Dose intensification of TRAIL-inducing ONC201 inhibits metastasis and promotes intratumoral NK cell recruitment. J. Clin. Investig. 2018, 128, 2325-2338. [CrossRef]

52. Khawaja, H.; Campbell, A.; Roberts, J.Z.; Javadi, A.; O’Reilly, P.; McArt, D.; Allen, W.L.; Majkut, J.; Rehm, M.; Bardelli, A.; et al. RALB GTPase: A critical regulator of DR5 expression and TRAIL sensitivity in KRAS mutant colorectal cancer. Cell Death Dis. 2020, 11, 930. [CrossRef]

53. Polanski, R.; Vincent, J.; Polanska, U.M.; Petreus, T.; Tang, E.K.Y. Caspase-8 activation by TRAIL monotherapy predicts responses to IAPi and TRAIL combination treatment in breast cancer cell lines. Cell Death Dis. 2015, 6, e1893. [CrossRef]

54. Sanmarco, L.M.; Wheeler, M.A.; Gutiérrez-Vázquez, C.; Polonio, C.M.; Linnerbauer, M.; Pinho-Ribeiro, F.A.; Li, Z.; Giovannoni, F.; Batterman, K.V.; Scalisi, G.; et al. Gut-licensed IFN $\gamma+$ NK cells drive LAMP1+TRAIL+ anti-inflammatory astrocytes. Nature 2021, 590, 473-479. [CrossRef]

55. White, C.A.; McCombe, P.A.; Pender, M.P. The roles of Fas, Fas ligand and Bcl-2 in T cell apoptosis in the central nervous system in experimental autoimmune encephalomyelitis. J. Neuroimmunol. 1998, 82, 47-55. [CrossRef]

56. Hilliard, B.; Wilmen, A.; Seidel, C.; Liu, T.-S.T.; Göke, R.; Chen, Y. Roles of TNF-Related Apoptosis-Inducing Ligand in Experimental Autoimmune Encephalomyelitis. J. Immunol. 2001, 166, 1314-1319. [CrossRef]

57. Pardridge, W.M.; Eisenberg, J.; Yang, J. Human Blood-Brain Barrier Insulin Receptor. J. Neurochem. 1985, 44, 1771-1778. [CrossRef] [PubMed]

58. Schwartz, M.W.; Sipols, A.; Kahn, S.E.; Lattemann, D.F.; Taborsky, G.J.; Bergman, R.N.; Woods, S.C.; Porte, D. Kinetics and specificity of insulin uptake from plasma into cerebrospinal fluid. Am. J. Physiol. Metab. 1990, 259, E378-E383. [CrossRef]

59. Kumthekar, P.; Tang, S.-C.; Brenner, A.J.; Kesari, S.; Piccioni, D.E.; Anders, C.K.; Carrillo, J.A.; Chalasani, P.; Kabos, P.; Puhalla, S.L.; et al. ANG1005, a Brain-Penetrating Peptide-Drug Conjugate, Shows Activity in Patients with Breast Cancer with Leptomeningeal Carcinomatosis and Recurrent Brain Metastases. Clin. Cancer Res. 2020, 26, 2789-2799. [CrossRef] [PubMed] 
60. Ashkenazi, A.; Pai, R.C.; Fong, S.; Leung, S.; Lawrence, D.A.; Marsters, S.A.; Blackie, C.; Chang, L.; McMurtrey, A.E.; Hebert, A.; et al. Safety and antitumor activity of recombinant soluble Apo2 ligand. J. Clin. Investig. 1999, 104, 155-162. [CrossRef] [PubMed]

61. Zhang, X.D.; Nguyen, T.; Thomas, W.D.; Sanders, J.E.; Hersey, P. Mechanisms of resistance of normal cells to TRAIL induced apoptosis vary between different cell types. FEBS Lett. 2000, 482, 193-199. [CrossRef]

62. Zauli, G.; Secchiero, P. The role of the TRAIL/TRAIL receptors system in hematopoiesis and endothelial cell biology. Cytokine Growth Factor Rev. 2006, 17, 245-257. [CrossRef]

63. Wosik, K.; Biernacki, K.; Khouzam, M.-P.; Prat, A. Death receptor expression and function at the human blood brain barrier. J. Neurol. Sci. 2007, 259, 53-60. [CrossRef]

64. Ridder, D.A.; Wenzel, J.; Müller, K.; Töllner, K.; Tong, X.-K.; Assmann, J.; Stroobants, S.; Weber, T.; Niturad, C.; Fischer, L.; et al. Brain endothelial TAK1 and NEMO safeguard the neurovascular unit. J. Exp. Med. 2015, 212, 1529-1549. [CrossRef]

65. Booth, R.; Kim, H. Characterization of a microfluidic in vitro model of the blood-brain barrier ( $\mu$ BBB). Lab Chip 2012, 12, 1784-1792. [CrossRef]

66. Yang, S.; Mei, S.; Jin, H.; Zhu, B.; Tian, Y.; Huo, J.; Cui, X.; Guo, A.; Zhao, Z. Identification of two immortalized cell lines, ECV304 and bEnd3, for in vitro permeability studies of blood-brain barrier. PLoS ONE 2017, 12, e0187017. [CrossRef] [PubMed]

67. Brown, R.C.; Morris, A.P.; O'Neil, R.G. Tight junction protein expression and barrier properties of immortalized mouse brain microvessel endothelial cells. Brain Res. 2007, 1130, 17-30. [CrossRef] [PubMed]

68. Yu, Y.J.; Zhang, Y.; Kenrick, M.; Hoyte, K.; Luk, W.; Lu, Y.; Atwal, J.; Elliott, J.M.; Prabhu, S.; Watts, R.J.; et al. Boosting Brain Uptake of a Therapeutic Antibody by Reducing Its Affinity for a Transcytosis Target. Sci. Transl. Med. 2011, 3, 84ra44. [CrossRef]

69. Haqqani, A.S.; Thom, G.; Burrell, M.; Delaney, C.E.; Brunette, E.; Baumann, E.; Sodja, C.; Jezierski, A.; Webster, C.; Stanimirovic, D.B. Intracellular sorting and transcytosis of the rat transferrin receptor antibody OX26 across the blood-brain barrierin vitrois dependent on its binding affinity. J. Neurochem. 2018, 146, 735-752. [CrossRef]

70. Niewoehner, J.; Bohrmann, B.; Collin, L.; Urich, E.; Sade, H.; Maier, P.; Rueger, P.; Stracke, J.O.; Lau, W.; Tissot, A.C.; et al. Increased Brain Penetration and Potency of a Therapeutic Antibody Using a Monovalent Molecular Shuttle. Neuron 2014, 81, 49-60. [CrossRef] [PubMed]

71. Kariolis, M.S.; Wells, R.C.; Getz, J.A.; Kwan, W.; Mahon, C.S.; Tong, R.; Kim, D.J.; Srivastava, A.; Bedard, C.; Henne, K.R.; et al. Brain delivery of therapeutic proteins using an Fc fragment blood-brain barrier transport vehicle in mice and monkeys. Sci. Transl. Med. 2020, 12, eaay1359. [CrossRef] [PubMed]

72. Hultqvist, G.; Syvänen, S.; Fang, X.T.; Lannfelt, L.; Sehlin, D. Bivalent Brain Shuttle Increases Antibody Uptake by Monovalent Binding to the Transferrin Receptor. Theranostics 2017, 7, 308-318. [CrossRef] [PubMed]

73. Webster, C.I.; Hatcher, J.; Burrell, M.; Thom, G.; Thornton, P.; Gurrell, I.; Chessell, I. Enhanced delivery of IL-1 receptor antagonist to the central nervous system as a novel anti-transferrin receptor-IL-1RA fusion reverses neuropathic mechanical hypersensitivity. Pain 2016, 158, 660-668. [CrossRef]

74. Bien-Ly, N.; Yu, Y.J.; Bumbaca, D.; Elstrott, J.; Boswell, C.; Zhang, Y.; Luk, W.; Lu, Y.; Dennis, M.S.; Weimer, R.M.; et al. Transferrin receptor (TfR) trafficking determines brain uptake of TfR antibody affinity variants. J. Exp. Med. 2014, 211, 233-244. [CrossRef]

75. Villaseñor, R.; Schilling, M.; Sundaresan, J.; Lutz, Y.; Collin, L. Sorting Tubules Regulate Blood-Brain Barrier Transcytosis. Cell Rep. 2017, 21, 3256-3270. [CrossRef] [PubMed]

76. Degli-Esposti, M.A.; Smolak, P.J.; Walczak, H.; Waugh, J.; Huang, C.-P.; DuBose, R.F.; Goodwin, R.G.; Smith, C.A. Cloning and Characterization of TRAIL-R3, a Novel Member of the Emerging TRAIL Receptor Family. J. Exp. Med. 1997, 186, 1165-1170. [CrossRef]

77. Degli-Esposti, M.A.; Dougall, W.C.; Smolak, P.J.; Waugh, J.Y.; Smith, C.A.; Goodwin, R.G. The Novel Receptor TRAIL-R4 Induces NF-kB and Protects against TRAIL-Mediated Apoptosis, yet Retains an Incomplete Death Domain. Immunity 1997, 7, 813-820. [CrossRef]

78. Uchida, Y.; Ohtsuki, S.; Katsukura, Y.; Ikeda, C.; Suzuki, T.; Kamiie, J.; Terasaki, T. Quantitative targeted absolute proteomics of human blood-brain barrier transporters and receptors. J. Neurochem. 2011, 117, 333-345. [CrossRef]

79. Agarwal, S.; Uchida, Y.; Mittapalli, R.K.; Sane, R.; Terasaki, T.; Elmquist, W.F. Quantitative Proteomics of Transporter Expression in Brain Capillary Endothelial Cells Isolated from P-Glycoprotein (P-gp), Breast Cancer Resistance Protein (Bcrp), and P-gp/Bcrp Knockout Mice. Drug Metab. Dispos. 2012, 40, 1164-1169. [CrossRef]

80. Shawahna, R.; Uchida, Y.; Declèves, X.; Ohtsuki, S.; Yousif, S.; Dauchy, S.; Jacob, A.; Chassoux, F.; Daumas-Duport, C.; Couraud, P.-O.; et al. Transcriptomic and Quantitative Proteomic Analysis of Transporters and Drug Metabolizing Enzymes in Freshly Isolated Human Brain Microvessels. Mol. Pharm. 2011, 8, 1332-1341. [CrossRef]

81. Gasparian, M.E.; Chernyak, B.V.; Dolgikh, D.A.; Yagolovich, A.V.; Popova, E.N.; Sycheva, A.M.; Moshkovskii, S.A.; Kirpichnikov, M.P.; Ekaterina, P. Generation of new TRAIL mutants DR5-A and DR5-B with improved selectivity to death receptor 5. Apoptosis 2009, 14, 778-787. [CrossRef] [PubMed]

82. Seifert, O.; Pollak, N.; Nusser, A.; Steiniger, F.; Rüger, R.; Pfizenmaier, K.; Kontermann, R.E. Immuno-LipoTRAIL: Targeted Delivery of TRAIL-Functionalized Liposomal Nanoparticles. Bioconjugate Chem. 2014, 25, 879-887. [CrossRef]

83. Seifert, O.; Plappert, A.; Fellermeier, S.; Siegemund, M.; Pfizenmaier, K.; Kontermann, R.E. Tetravalent Antibody-scTRAIL Fusion Proteins with Improved Properties. Mol. Cancer Ther. 2013, 13, 101-111. [CrossRef] [PubMed] 
84. McQuin, C.; Goodman, A.; Chernyshev, V.; Kamentsky, L.; Cimini, B.A.; Karhohs, K.W.; Doan, M.; Ding, L.; Rafelski, S.M.; Thirstrup, D.; et al. CellProfiler 3.0: Next-generation image processing for biology. PLoS Biol. 2018, 16, e2005970. [CrossRef] [PubMed] 